\title{
Harmonisation and trends of 20-year tropical tropospheric ozone data
}

\author{
Elpida Leventidou $^{1}$, Mark Weber ${ }^{1}$, Kai-Uwe Eichmann ${ }^{1}$, John P. Burrows ${ }^{1}$, Klaus-Peter Heue ${ }^{2}$, Anne M. Thompson ${ }^{3}$, \\ and Bryan J. Johnson ${ }^{4}$ \\ ${ }^{1}$ Institute of Environmental Physics (IUP), University of Bremen, Bremen, Germany \\ ${ }^{2}$ Deutsches Zentrum für Luft- und Raumfahrt, Münchener Str. 20, 82234 Oberpfaffenhofen, Germany \\ ${ }^{3}$ NASA Goddard Space Flight Center, Greenbelt, Maryland, USA \\ ${ }^{4}$ Global Monitoring Division, NOAA ESRL, Boulder, Colorado, USA
}

Correspondence: E. Leventidou (levent@iup.physik.uni-bremen.de)

Received: 31 August 2017 - Discussion started: 27 September 2017

Revised: 25 May 2018 - Accepted: 5 June 2018 - Published: 3 July 2018

\begin{abstract}
Using a convective-cloud differential (CCD) method, developed in-house and applied to retrievals of total ozone and cloud data from three European satellite instruments (viz. GOME/ERS-2, 1995-2003; SCIAMACHY/Envisat, 2002-2012 and GOME-2/MetOp-A, 2007-2015), monthly mean tropical tropospheric columns of ozone (TTCO) have been retrieved, which are in good agreement with ozonesondes (biases less than 6DU). As small differences in TTCO between the individual instruments were evident, it was necessary to develop a scheme to harmonise the three datasets into one consistent time series starting from 1996 until 2015. Correction offsets (biases) between the instruments using SCIAMACHY as intermediate reference have been calculated and six different harmonisation or merging scenarios have been evaluated. Depending on the merging approach, the magnitude, pattern and uncertainty in the trends strongly vary. The harmonisation or merging represents an additional source of uncertainty in the trends ( $2 \mathrm{DU}$ decade $^{-1}$ on average, in most of the cases exceeding the uncertainty from the regression). For studying further details on tropospheric ozone trends on various spatial scales in the tropics, we stick with one preferred merged dataset that shows best agreement with ozonesondes. In this merged dataset, no correction was applied for GOME, and mean biases with respect to SCIAMACHY in the overlapping period (2007-2012) were calculated and applied for GOME-2 in each grid box $\left(2.5^{\circ} \times 5^{\circ}\right)$. In contrast with other studies we found that the tropospheric trend averaged over the tropics $\left(-15^{\circ} \mathrm{S}\right.$ to $\left.15^{\circ} \mathrm{N}\right)$ is not
\end{abstract}

statistically significant. The mean tropospheric ozone trend equals $-0.2 \pm 0.6 \mathrm{DU}_{\text {decade }}{ }^{-1}(2 \sigma)$. Regionally, tropospheric ozone has a statistically significant increase of $\sim 3$ DU decade ${ }^{-1}$ over southern Africa $\left(\sim 1.5 \% \mathrm{yr}^{-1}\right)$, the southern tropical Atlantic $\left(\sim 1.5 \% \mathrm{yr}^{-1}\right)$, southeastern tropical Pacific Ocean $\left(\sim 1 \% \mathrm{yr}^{-1}\right)$, and central Oceania $\left(\sim 2 \% \mathrm{yr}^{-1}\right)$ and by $\sim 2 \mathrm{DU}$ decade $^{-1}$ over central Africa $\left(2-2.5 \% \mathrm{yr}^{-1}\right)$ and south India $\left(\sim 1.5 \% \mathrm{yr}^{-1}\right)$. On the other hand, tropospheric $\mathrm{O}_{3}$ decreases by $\sim 3 \mathrm{DU}$ decade ${ }^{-1}$ over the Caribbean Sea and parts of the North Pacific Ocean $\left(\sim 2 \% \mathrm{yr}^{-1}\right)$, and by less than $2 \mathrm{DU}$ decade $^{-1}$ over some regions of the southern Pacific and Indian oceans $\left(\sim 0.5-1 \% \mathrm{yr}^{-1}\right)$.

\section{Introduction}

As is well known since the industrial revolution, the Earth's population and its standard of living have grown dramatically. At the same time the urban population has grown. Since 2011, more than $50 \%$ of the world's population live in urban areas and the population has now passed 7.5 billion. In the past two decades, the population has grown by more than 2 billion. An increasing population and standard of living inevitably leads to increased energy consumption, which is used in industry, transportation and food production. These human activities release a large number of atmospheric pollutants which can be harmful to public health and/or vegetation and modify the terrestrial climate (Crutzen, 
2002). Climate change may also impact air pollution events (WMO/IGAC, 2012). Tropospheric ozone $\left(\mathrm{O}_{3}\right)$ is regarded as one of the most important surface pollutants. This is because it oxidises the biological tissues causing respiratory problems or even death (WHO, 2006), acts as a greenhouse gas (IPCC, 2007) and controls the oxidising capacity of the troposphere (Jacob, 2000). $\mathrm{O}_{3}$ in the troposphere is expected to increase by 60 to $80 \%$ by 2050 in Southeast Asia, India and Central America under the A2 IPCC (2013) scenario. However, the effects of climate change, especially the increased tropospheric temperatures and water vapour, may offset this increase by 10 to $17 \%$ (Stevenson et el., 2000; Grewe et al., 2001; Hauglustaine et al., 2005; IPCC, 2013).

Ozone is not directly emitted in the troposphere but it is a byproduct of the oxidation of volatile organic compounds (VOCs) in the presence of nitrogen oxides $\left(\mathrm{NO}_{x}\right)$ and sunlight (Crutzen, 1970; Chameides and Walker, 1973). Young et al. (2013) estimated that $4877 \pm 1706 \mathrm{Tg}(2 \sigma)$ of $\mathrm{O}_{3}$ are chemically produced every year. Additionally, $477 \pm 392 \mathrm{Tg} \mathrm{yr}^{-1}$ are transported from the stratosphere to the troposphere via the stratosphere to troposphere exchange (STE) (Holton and Lelieveld, 1996; Young et al., 2013). Tropospheric ozone loss is controlled by deposition to the Earth's surface and chemical destruction, mainly by photolysis to atomic oxygen $\left(\mathrm{O}\left({ }^{1} \mathrm{D}\right)\right)$, followed by the reaction of $\mathrm{O}\left({ }^{1} \mathrm{D}\right)$ with water $\left(\mathrm{H}_{2} \mathrm{O}\right)$ to produce two hydroxyl radicals $(2 \mathrm{OH})($ Levy, 1972). The net chemical production (production minus loss) is estimated at $618 \pm 550 \mathrm{Tg} \mathrm{yr}^{-1}(2 \sigma)$ (Young et al., 2013; IPCC, 2013). The mean tropospheric ozone burden is $337 \pm 46 \mathrm{Tg}(2 \sigma)$ today, which is about $30 \%$ more than in 1850 (Young et al., 2013).

The sources of ozone precursors (VOCs and $\mathrm{NO}_{x}$ ) can be both of anthropogenic and natural origin. Various efforts towards reducing $\mathrm{NO}_{x}$ and $\mathrm{VOC}$ emissions have been taken in developed countries, particularly in Europe and North America, leading to negative surface ozone trends on a local scale (Derwent et al., 2003; Cooper et al., 2014; Parrish et al., 2014). Nevertheless, tropospheric ozone pollution is a matter of global concern, because ozone and its precursors are transported from polluted areas to clean regions over continental distances and into the free troposphere through atmospheric dynamics, increasing the tropospheric ozone abundances over remote areas. For example, air masses originated from eastern China have increased ozone abundance over Japan and North America's west coast, despite the US legislation of reducing $\mathrm{NO}_{x}$ emissions (Parrish et al., 2009; Cooper et al., 2010; Oltmans et al., 2013; Verstraeten et al., 2016). Additionally, the high tropospheric ozone amounts noticed over the south Atlantic ocean, the so-called "tropical Atlantic paradox", arise from ozone precursor emissions by biomass burning taking place in South America and Africa (Thompson et al., 2000; Diab et al., 2003).

The long-term evolution of tropospheric ozone is complex and depends upon the evolution of precursor emissions and climate change. As the predicted increase in trace gas emissions for the next years is mainly located over low latitudes (Grenfell et al., 2003), long-term observations of tropospheric ozone in the tropics should receive particular attention. Various studies have been performed in urban and rural sites using in situ data in order to estimate tropical tropospheric ozone trends. Lelieveld et al. (2004) noticed an increase in surface ozone of the order of $0.4 \mathrm{ppbv} \mathrm{yr}^{-1}$ over the northeastern tropical Atlantic, $0.4 \mathrm{ppbv} \mathrm{yr}^{-1}$ over the southeastern tropical Atlantic and a smaller trend of $0.1 \mathrm{ppbv}$ decade $^{-1}$ over the southwestern tropical Atlantic Ocean, based on ship-borne measurements (1977-2002). Oltmans et al. (2013) observed an increase of $3.8 \%$ decade $^{-1}\left(0.16 \mathrm{ppbv} \mathrm{yr}^{-1}\right)$ in surface ozone in Mauna Loa, Hawaii $\left(19.5^{\circ} \mathrm{N}\right)$ in the North Pacific since 1974 and a smaller insignificant trend of the order of $0.7 \%$ decade $^{-1}$ $\left(0.01 \mathrm{ppbv} \mathrm{yr}^{-1}\right)$ in American Samoa $\left(-14.5^{\circ} \mathrm{S}\right)$ after 1976. Additionally, Cooper et al. (2014) report a significant increase of $0.19 \mathrm{ppbv} \mathrm{yr}^{-1}$ in the subtropical site of Cape Point in South Africa from 1983 to 2011. Thompson et al. (2014) using ozonesonde data from the SHADOZ stations in Irene $\left(-25.9^{\circ} \mathrm{S},-28.2^{\circ} \mathrm{W}\right)$ and Réunion $\left(-21.1^{\circ} \mathrm{S}\right.$, $-55.5^{\circ} \mathrm{W}$ ) noticed statistically significant trends in the middle and upper troposphere of $\sim 25 \%$ decade $^{-1}\left(1 \mathrm{ppbv} \mathrm{yr}^{-1}\right)$ and $\sim 35-45 \%$ decade $^{-1}\left(2 \mathrm{ppbv} \mathrm{yr}^{-1}\right)$, respectively, during winter (June-August). Smaller positive trends appear close to the tropopause in summer.

Satellite remote sensing is required to perform trend analysis up to the global scale. One key challenge to retrieve tropospheric ozone column amounts from the measurements of satellite remote sensing instrumentation is the accurate subtraction of stratospheric ozone from the total column ozone. This requires accurate knowledge of the pressure or altitude level at which the tropopause is located. However, in the tropics, where the tropopause is not strongly modulated by frontal systems, the retrieval uncertainties due to the dayto-day variability in the tropopause can be reduced using monthly averages (Jensen, 2012). Most of the methods of estimating tropospheric ozone columns from space in the tropics derive from the residual approach of Fishman and Larsen (1987) and Fishman et al. (1990). Later, more methods were developed such us the scan angle method from Kim et al. (1996), a modified residual method from Thompson and Hudson (1999), the convective-cloud differential (CCD) from Ziemke et al. (1998), the cloud slicing (CS) technique from Ziemke et al. (2005), a modified trajectory-enhanced tropospheric ozone residual method (TTOR) from Schoeberl et al. (2007) and Doughty et al. (2011) and the limb-nadir matching (LNM) method from Ebojie et al. (2014).

These methods have provided valuable datasets with which tropospheric ozone trends have been derived in the tropics. For example, Ziemke et al. (2005), using the CCD method on the Total Ozone Mapping Spectrometer (TOMS) version 8 data from 1979 to 2003 , found a statistically significant positive linear trend in the mid-latitudes but not in the tropics. Beig and Singh (2007) using the same data found 
an increasing trend of $7-9 \%$ decade $^{-1}$ over some parts of south Asia, 4-6\% decade ${ }^{-1}$ over the Bay of Bengal and 2$3 \%$ decade $^{-1}$ over the central Atlantic Ocean and central Africa up to 2005. Kulkarni et al. (2010), using tropospheric ozone residual (TOR) data from TOMS, SAGE and SBUV instruments, calculated statistically significant trends over three Indian mega-cities during 1979-2005. They showed that ozone increased by $3.4 \%$ decade $^{-1}$ in Delhi during the monsoon period, while it increased by $3.4-4.7 \%$ decade $^{-1}$ in Hyderabad and 5-7.8\% decade $^{-1}$ in Bengaluru (formerly known as Bangalore) during pre-monsoon and post-monsoon periods. One objective of the SCIAMACHY proposal in 1988 (Burrows et al., 1995 and references therein) was the retrieval of tropospheric ozone by making limb and nadir observations in the backscattered and reflected solar radiation. Ebojie et al. (2016) using the full record of SCIAMACHY limb-nadir-matching data (2002-2011), retrieved regional and global tropospheric ozone trends. An insignificant positive trend of the order of $0.5 \mathrm{DU}_{\text {decade }}{ }^{-1}$ was noticed for the northern tropics $\left(0\right.$ to $\left.20^{\circ} \mathrm{N}\right)$ and of the order of $0.3 \mathrm{DU}$ decade ${ }^{-1}$ in the southern tropics $\left(0\right.$ to $\left.-20^{\circ} \mathrm{S}\right)$. Regionally, they reported statistically significant trends of $-1.6 \% \mathrm{yr}^{-1}$ over northern South America $\left(0\right.$ to $-10^{\circ} \mathrm{S}$, -75 to $\left.-45^{\circ} \mathrm{W}\right)$, of $1.6 \% \mathrm{yr}^{-1}$ in southern Africa ( -5 to $-15^{\circ} \mathrm{S}, 25$ to $35^{\circ} \mathrm{E}$ ), of $1.9 \% \mathrm{yr}^{-1}$ over Southeast Asia ( 15 to $35^{\circ} \mathrm{N}, 80$ to $115^{\circ} \mathrm{E}$ ), and a trend of $1.2 \% \mathrm{yr}^{-1}$ over northern Australia ( -20 to $-10^{\circ} \mathrm{S}, 100$ to $\left.130^{\circ} \mathrm{E}\right)$. Most recently, Heue et al. (2016) published a study about tropical tropospheric ozone trends using the CCD method on a harmonised dataset consisting of data retrieved from GOME, SCIAMACHY, GOME-2 and OMI satellite instruments from July 1995 to December 2015, which are based upon different total ozone and cloud retrievals as well as merging approaches. The mean tropical tropospheric ozone trend that they found is $0.7 \mathrm{DU}$ decade $^{-1}$ and regionally the trend reaches 1.8 DU decade ${ }^{-1}$ near the African Atlantic coast, and -0.8 DU decade ${ }^{-1}$ over the western Pacific. Seasonally, they found that the trend over the south African coast maximises in summer, whereas the negative trend over the southwest $\mathrm{Pa}$ cific Ocean maximises during autumn. As discussed earlier, the trend results from the various studies vary significantly, and in some cases they do not agree with each other, even though the same dataset was used.

Using a CCD method developed at the Institute of Environmental Physics (IUP) at the University of Bremen and applied to retrievals of total ozone and cloud data from GOME/ERS-2 (1995-2003), SCIAMACHY/Envisat (20022012) and GOME-2/MetOp-A (2007-2015), new datasets of monthly mean tropical tropospheric columns of ozone (TTCO) have been created (Leventidou et al., 2016). The main differences between our CCD algorithm and the one developed by Heue et al. (2016) mainly originate from the different corrections that we have applied in the above-cloud column calculation of GOME and GOME-2 data and handling of the outlier data (Leventidou et al., 2016). The main goal of this study is to derive long-term trends from our merged CCD tropical tropospheric ozone datasets. In a first step the three satellite data are merged into a consistent longterm dataset. Six possible approaches for merging the data are considered and evaluated by comparisons to SHADOZ ozonesondes and by trend evaluations (Sect. 2). The comparisons to ozonesonde, among other criteria, are used to identify the preferred merging scenario. The trend evaluation of the six merging scenarios will allow us to roughly estimate the contribution of the merging approach to trend uncertainties. In Sect. 3 the multi-linear regression model is briefly described. Detailed trend results for the tropics $-15^{\circ} \mathrm{S}$ to $15^{\circ} \mathrm{N}$, as well as for selected regions, are presented in Sect. 4 for the preferred merged dataset. This paper ends with a summary and discussion (Sect. 5).

\section{Harmonisation and merging of the TTCO datasets}

\subsection{Tropical tropospheric $\mathrm{O}_{3}$ data}

Monthly mean TTCO data have been retrieved as reported by Leventidou et al. (2016) using the convective-cloud differential (CCD) method on GOME (Burrows et al., 1999) SCIAMACHY (Burrows et al., 1995; Bovensmann et al., 1999), and GOME-2 (Callies et al., 2000) total ozone and cloud data from 1996 to 2015. These instruments have different properties such as spatial resolution, cloud algorithms, overpass time, etc. The individual TTCO datasets have been created taking into account these specific characteristics. The individual TTCO datasets have been separately validated with integrated (up to $200 \mathrm{hPa}$ ) tropospheric ozone columns by ozonesondes from the SHADOZ network (Thompson et al., 2003) (see: Leventidou et al., 2016). The biases between them have been found to be within the uncertainties in the mean biases of $6 \mathrm{DU}(1 \sigma)$. A large source of uncertainties in these comparisons are the low sampling of the sondes (typically less than five launches in a month) and the fact that CCD ozone is only derived as monthly means covering rather large areas (grid box). The uncertainty in the tropospheric ozone column retrieval with the CCD method is of the order of $3 \mathrm{DU}(\sim 10 \%)$. For most of the stations, the bias with the ozonesondes is within the retrieval uncertainty, with the exception of GOME-2 TTCO which is of the order of $-5 \mathrm{DU}$. Finally, the CCD TTCO from SCIAMACHY data have been compared with the limb-nadir matching (LNM) tropospheric $\mathrm{O}_{3}$ columns up to $200 \mathrm{hPa}$ altitude from the same satellite instrument, showing that the bias and the RMSE values are within the ones calculated for the comparison with ozonesondes.

\subsection{Correction offsets between GOME and GOME-2 with respect to SCIAMACHY TTCO}

For trend calculations the existence of a constant bias (in clouds and ozone) between the instruments, caused by the 
spatial and temporal differences of the individual instruments, can be removed by using a suitable merging approach as will be shown here. Correction offsets have been calculated in order to create one consistent tropical tropospheric columns dataset from the CCD method for the whole timespan of the operation of the European satellites (1996-2015). SCIAMACHY TTCO were used as the reference, because SCIAMACHY is the only instrument that overlaps (20022012) both with GOME and GOME-2 and has the smallest bias with respect to the ozonesondes $(<2 \mathrm{DU})$. The average difference (bias) for each grid box during the common years of the instruments operation (2002 for SCIAMACHYGOME and 2007-2012 for SCIAMACHY-GOME-2) was computed and applied (added) to GOME and GOME-2 TTCO data. The mean biases, shown in Fig. 1, range between -6 and 6 DU for GOME, with positive differences (3-6 DU) located mainly over land. There are also two regions with positive biases appearing north of 7.5 to $20^{\circ} \mathrm{N}$, and between -5 and $-7.5^{\circ} \mathrm{S}$. For GOME-2, the bias ranges between -8 and $0 \mathrm{DU}$, being smaller over land, especially over South America and north and central Africa. Possible reasons for the biases are the different cloud algorithms used for each instrument (SACURA for SCIAMACHY and FRESCO for GOME and GOME-2) and the small biases noticed in the total ozone columns (e.g. $\sim-2.5$ DU between SCIAMACHY and GOME-2). Differences in spatial resolution and overpass time of the instruments have also minor contributions to the biases.

The latitudinal dependence of the mean bias is shown at the bottom of Fig. 1. The average differences between GOME and GOME-2 with SCIAMACHY are generally negative (less than $5 \mathrm{DU}$ ) in all latitude bands with the exception of the northern tropical latitudes, where GOME mean biases are positive (0-2 DU). GOME mean biases have stronger latitudinal variability than those of GOME-2. This behaviour may be explained by the short time of common operation (January 2002-June 2003) between GOME and SCIAMACHY instruments. The $1 \sigma$ standard deviation (uncertainty bars) of the mean bias per latitude band is comparable to the magnitude of the biases, ranging from less than $5 \mathrm{DU}$ close to the equator to $7 \mathrm{DU}$ for latitude bands close to the tropical borders. For the case of GOME, the mean correction offset is $-1.2 \mathrm{DU}$, whereas for GOME-2 it is $-5.7 \mathrm{DU}$. The mean offset of GOME-2 is almost twice the CCD retrieval uncertainty ( $\sim 3 \mathrm{DU})$. For this reason, and because of the large biases with the ozonesonde data, it seems reasonable to apply a correction for the GOME-2 TTCO dataset.

The drift on the average differences (bias $\beta$ ) has been estimated using a simple linear regression model such as $Y=\alpha+\beta \cdot X_{t}$, where $Y$ is the time series of the biases, $X_{t}$ is the time variable in months and $\alpha$ is the offset. The drift between SCIAMACHY and GOME-2 is shown in Fig. 2. There are not enough overlapping years to calculate a trend in the GOME-SCIAMACHY difference time series. The drift is generally less than $\sim 0.4 \mathrm{DU} \mathrm{yr}^{-1}$ and is statistically not sig-
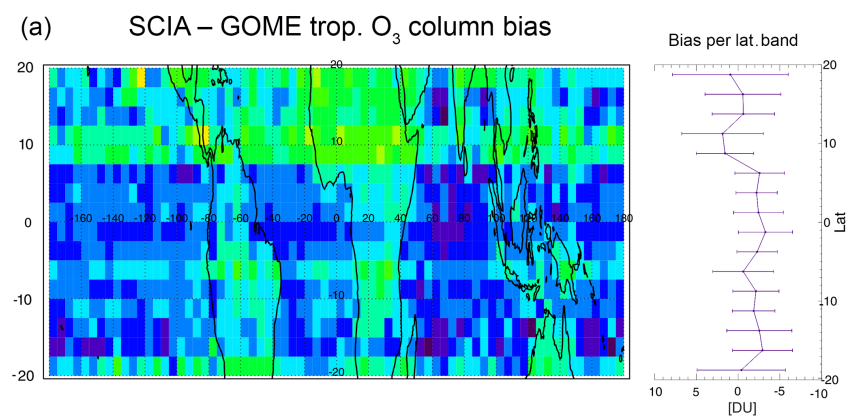

(b) SCIA - GOME-2 trop. $\mathrm{O}_{3}$ column bias

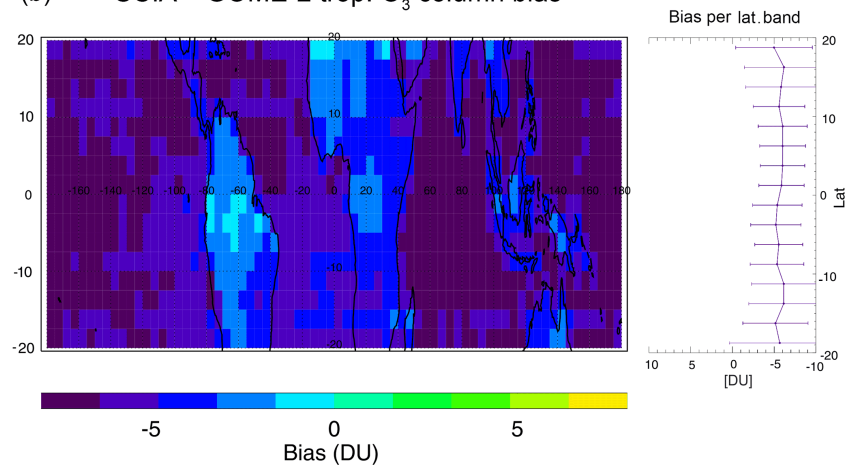

Figure 1. Correction offsets using SCIAMACHY TTCO as reference. (a) Correction offset for GOME: average difference of GOME from SCIAMACHY TTCO for the years 2002-2003. (b) Correction offset for GOME-2: average difference of GOME-2 from SCIAMACHY TTCO (in DU) for the years 2007-2012. On the right are shown the biases per latitude band. The error bars denote the $1 \sigma$ standard deviations of the latitudinally averaged biases.

nificant $\left(\beta / \sigma_{\beta}<2\right.$; Weatherhead et al., 1998; Wilks, 2011) for nearly all grid boxes, with the exception of the 17.5 to $20^{\circ} \mathrm{N}$ latitude band, where it is statistically significant and exceeds $1 \mathrm{DU} \mathrm{yr}^{-1}$. During local winter months at the tropical borders, there are often missing TTCO data owing to the movement of the Intertropical Convergence Zone (ITCZ) and the inability to retrieve a reliable stratospheric $\mathrm{O}_{3}$ column. For this reason, calculated drifts for these latitudes are not reliable, in spite of the fact that they might appear to be statistically significant. Consequently, the trend of the correction offsets is considered to be negligible.

\subsection{Six harmonisation scenarios}

The creation of a consistent tropical tropospheric ozone column dataset from multiple satellite instruments demands a careful selection of the optimal harmonisation approach, since it introduces additional uncertainty in the merged dataset. Six harmonisation scenarios have been tested. They all use the SCIAMACHY TTCO dataset as a reference, which is in the middle of the time period, as follows:

- scenario 1: no correction applied to GOME data (which may be justified by the very short overlap period), while 
(a) SCIA - GOME-2 trop. $\mathrm{O}_{3}$ column bias drift

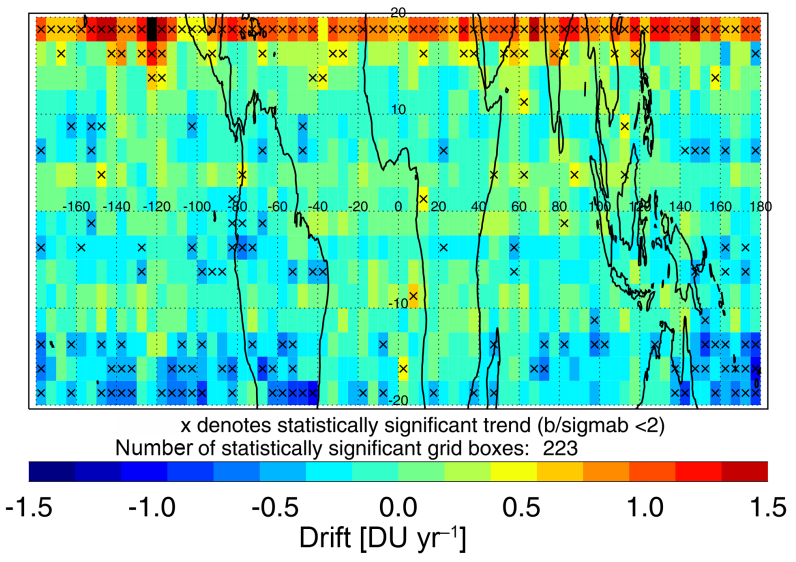

(b) SCIA - GOME-2 mean trop. $\mathrm{O}_{3}$ column bias

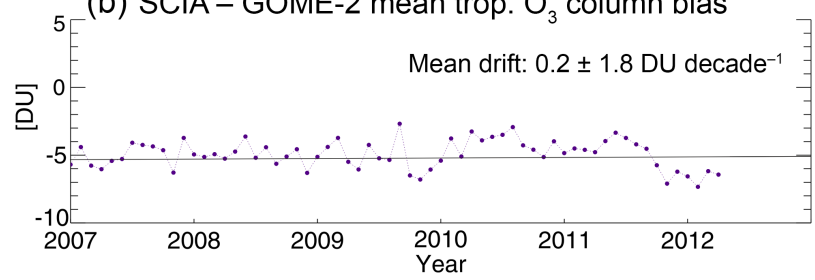

Figure 2. (a) Drift in the correction offset for GOME-2. Black " $x$ " denotes statistically significant trend. (b) Average difference and drift in the correction offset for GOME-2 between 2007 and 2012.

GOME-2 is corrected using the mean bias with respect to SCIAMACHY for each grid box for the common years of operation (2007-2012 for GOME-2).

- scenario 2: no correction is applied to GOME data and the average bias $(-5.7 \mathrm{DU})$ with respect to SCIAMACHY is added to all GOME-2 TTCO data.

- Scenario 3: GOME and GOME-2 have been corrected using for each grid box the mean bias with respect to SCIAMACHY for the common years of operation.

- scenario 4: the average bias with respect to SCIAMACHY $(-1.2 \mathrm{DU})$ is added to all GOME TTCO data, whereas GOME-2 TTCO has been corrected using the mean bias with respect to SCIAMACHY for each grid box for the common years of operation (2002 for GOME and 2007-2012 for GOME-2).

- scenario 5: the average bias with respect to SCIAMACHY for GOME (-1.2 DU) and for GOME-2 $(-5.7 \mathrm{DU})$ is added to all GOME and GOME-2 TTCO data, respectively.

- scenario 6: no correction is applied to GOME, whereas for GOME-2 both the bias and the drift is included in the correction of GOME-2 TTCO in each grid box.
After the correction terms for all scenarios have been applied to the original data, the "corrected" GOME (19962002) and GOME-2 (2007-2015) TTCO were averaged with the ones from SCIAMACHY (2003-2012) for the overlapping months (January 2002-June 2003 and January 2007December 2012, respectively).

In order to decide which is the most suitable harmonisation scenario, the various merged datasets were compared with integrated ozone columns up to $200 \mathrm{hPa}$ altitude from nine ozonesonde stations: (a) Ascension $\left(-8^{\circ} \mathrm{S},-14.4^{\circ} \mathrm{W}\right)$, (b) Paramaribo $\left(5.8^{\circ} \mathrm{N},-55.2^{\circ} \mathrm{W}\right)$, (c) Java $\left(-7.6^{\circ} \mathrm{S},-111^{\circ} \mathrm{E}\right)$, (d) Natal $\left(-5.4^{\circ} \mathrm{S},-35.4^{\circ} \mathrm{W}\right)$, (e) Samoa $\left(-14.4^{\circ} \mathrm{S},-170.6^{\circ} \mathrm{W}\right)$, (f) Nairobi $\left(-1.4^{\circ} \mathrm{S}\right.$, $\left.36.8^{\circ} \mathrm{E}\right)$ and $(\mathrm{g})$ Kuala Lumpur $\left(-2.7^{\circ} \mathrm{S}, 101.7^{\circ} \mathrm{E}\right)$. Fiji $\left(-18.1^{\circ} \mathrm{S},-178.4^{\circ} \mathrm{E}\right)$ station is not included in the comparison because it is highly influenced by air coming in from mid-latitudes and the upper troposphere (Thompson et al., 2017). Hilo $\left(19.4^{\circ} \mathrm{N},-155.4^{\circ} \mathrm{W}\right)$ is strongly affected by volcanic outgassing which interferes with the ozonesondes' electrochemical concentration cells, resulting in negligible ozone concentrations being measured in the boundary layer (Morris et al., 2010). Therefore, this station is also not included. As seen in Table 1, the mean bias between the six harmonised TTCO datasets and the ozonesondes range between -1.1 and $0.9 \mathrm{DU}$ which is well within the retrieval uncertainty showing that for most scenarios the spatio-temporal offsets with respect to ozonesondes are minimised. However, the biases of each scenario with ozonesondes are very close to each other for every station. The same occurs for the correlation between the harmonised TTCO datasets and the ozonesondes (not shown here). Although the comparison between the TTCO from the individual harmonised scenarios and the ozonesonde data does not clearly favour any harmonisation scenario, the scenarios that can be confidently rejected are scenarios 3, 4 and 5, where GOME data are corrected with respect to SCIAMACHY since the overlap period between GOME and SCIAMACHY is very short (10 months, August 2002-June 2003). Scenario 6 can also be rejected due to the fact that the drift in GOME-2 correction offset at $81 \%$ of the grid boxes is statistically non-significant. Lack of significant drifts in the comparison between GOME- 2 and SCIAMACHY over the overlapping period shows that the data records are quite stable. Scenarios 1 and 2 have the smallest bias with respect to ozonesondes; however, both show some differences in regional trends with scenario 1 having larger regions with statistically significant trends, while scenario 2 shows mostly zero trends across the tropics within their uncertainties (see the Supplement). The main difference between scenario 2 and 1 is that the former uses a single (global) bias correction for GOME-2, while scenario 1 biases are corrected individually for each grid box, which we believe makes physically more sense given the long overlap period. For these reasons, scenario 1 (no drift corrections and bias correction for GOME-2), which also has the smallest mean bias with the ozonesondes $(-0.4 \mathrm{DU})$, has been se- 
Table 1. Mean differences (in DU) between merged TTCO data, retrieved with the CCD method using six possible harmonisation scenarios, with integrated ozone columns up to $200 \mathrm{hPa}$ from nine SHADOZ stations. The stations marked with an asterisk $\left(^{*}\right)$ present data from the newest reprocessed (V05.1_R) version (Thompson et al., 2007; Witte, 2017). The regions where the merged scenarios have the smallest biases with the ozonesondes are marked with bold. Scenario 1 has the smallest mean bias for all the stations.

\begin{tabular}{lrrrrrr}
\hline CCD - sondes TTCO (DU) per site & Scenario & Scenario & Scenario & Scenario & Scenario & Scenario \\
& 1 & 2 & 3 & 4 & 5 & 6 \\
\hline American Samoa $\left(-14.4^{\circ} \mathrm{S},-170.6^{\circ} \mathrm{W}\right)^{*}$ & -0.89 & -0.92 & -1.99 & $-\mathbf{0 . 6 1}$ & -0.93 & 4.59 \\
Ascension $\left(-8^{\circ} \mathrm{S},-14.4^{\circ} \mathrm{W}\right)$ & $\mathbf{0 . 0 3}$ & -0.14 & -0.77 & -0.42 & -0.60 & $\mathbf{0 . 0 3}$ \\
Java $\left(-7.6^{\circ} \mathrm{S}, 111^{\circ} \mathrm{E}\right)$ & $-\mathbf{0 . 1 1}$ & -0.12 & -1.12 & -0.54 & -0.55 & $-\mathbf{0 . 1 1}$ \\
Kuala Lumpur $\left(2.7^{\circ} \mathrm{N}, 101.7^{\circ} \mathrm{E}\right)$ & -1.81 & -2.12 & -2.12 & -2.14 & -2.48 & $-\mathbf{1 . 7 8}$ \\
Nairobi $\left(-1.3^{\circ} \mathrm{S}, 36.8^{\circ} \mathrm{E}\right)$ & 1.81 & 1.10 & 1.80 & 1.48 & $\mathbf{0 . 7 4}$ & 1.84 \\
Natal $\left(-5.4^{\circ} \mathrm{S},-35.4^{\circ} \mathrm{W}\right)$ & 0.56 & 0.63 & $-\mathbf{0 . 2 1}$ & 0.22 & 0.28 & 0.57 \\
Paramaribo $\left(5.8^{\circ} \mathrm{N},-55.2^{\circ} \mathrm{W}\right)^{*}$ & -2.98 & -2.95 & -3.02 & -4.11 & -4.34 & $-\mathbf{0 . 1 1}$ \\
\hline Mean bias for all stations & $-\mathbf{0 . 4 8}$ & -0.64 & -1.06 & 0.87 & -1.13 & 0.72 \\
\hline
\end{tabular}

lected to be the preferred harmonisation scenario for merging the TTCO datasets. Before we discuss tropical tropospheric trends using the preferred scenario in detail (Sect. 5), we try to estimate the potential contribution of the merging approaches to trend uncertainties in tropical tropospheric ozone.

\subsection{Sensitivity of the trend to the merging approach}

The statistical trend uncertainty derived from a single dataset usually does not account for uncertainties due to the merging approach applied. Here we will provide a rough estimate on how large the trend uncertainties may be. We applied the multivariate linear regression model (see Sect. 3, Eq. (1) for details on the regression) to derive trends from all six merged datasets. The tropospheric $\mathrm{O}_{3}$ trends from all scenarios range between $\sim-4$ and $4 \mathrm{DU}$ decade $^{-1}$, with mean values between 0 and $0.8 \mathrm{DU}$ decade $^{-1}$, without any of them being statistically significant for the global tropics (see Fig. S1 in the Supplement). The maximum trend difference among all six harmonisation scenarios is on average $2 \mathrm{DU}$ decade $^{-1}$ exceeding the $2 \sigma_{\beta}$ uncertainty in the trends, which is $\sim 1.2 \mathrm{DU}$ decade ${ }^{-1}$ (see Fig. S2 in the Supplement). These differences in the trends among the differently harmonised datasets reveal the additional uncertainty which results from the harmonisation procedure of multiple TTCO datasets.

\section{The multi-linear regression trend model}

Changes in ozone precursor emissions due to urbanisation and land use, along with changes in the atmospheric dynamics which impact tropical upwelling or the horizontal ozone transport, may cause long-term changes in the tropospheric ozone burden. This in turn impacts the photochemical ozone production and loss in the troposphere (Ziemke and Chandra, 2003; Solomon et el., 2007; Chandra et al., 2009; Voulgar- akis et al., 2010; WMO, 2011; Neu et al., 2014; Monks et al., 2015). Some of these factors can be represented by periodic seasonal proxies, such as the El Niño Southern Oscillation (ENSO), the quasi-biennial oscillation (QBO) and the solar cycle (SC). These indexes are embodied in the trend model described here.

The time series of the monthly mean tropical tropospheric ozone columns $Y_{t}$ at a specific latitude and longitude $(i, j)$ (running every 2.5 and $5^{\circ}$, respectively) is described by the following trend model:

$$
\begin{aligned}
Y_{t}(i, j) & =\alpha(i, j)+\beta(i, j) \cdot X_{t}+S_{t}(i, j)+R_{t}(i, j) \\
& +N_{t}(i, j)
\end{aligned}
$$

where $a$ is the offset for the first month $t=1, \beta$ the linear trend in DU month ${ }^{-1}, X$ the time variable (months running from zero to 239) covering the years 1996-2015, $S_{t}$ is the seasonal variation, $R_{t}$ are the terms with the various proxies (ENSO, QBO, SC) and $N_{t}$ is the noise of the time series, representing the unexplained portion of the variability in the fit. The seasonal cycle is modelled by a Fourier series (see Eq. 2), with $\gamma_{11}, \gamma_{21}, \gamma_{12}, \gamma_{22}, \gamma_{13}, \gamma_{23}$ being the regression coefficients for 12-, 6- and 4-month periodicities, with sine and cosine terms for each periodicity, respectively:

$$
\begin{aligned}
S_{t}(i, j) & =\sum_{n=1}^{3}\left(\gamma_{1_{n}} \cdot \sin \left(\frac{2 \cdot \pi \cdot n \cdot t}{12}\right)+\gamma_{2_{n}}\right. \\
& \left.\cdot \cos \left(\frac{2 \cdot \pi \cdot n \cdot t}{12}\right)\right)
\end{aligned}
$$

$R_{t}$, represents the time-dependent regression coefficients for the ENSO, QBO and solar cycle proxies which can be expressed as

$$
R_{t}=\delta \cdot \mathrm{ENSO}_{t}+\varepsilon \cdot \mathrm{QBO}_{30_{t}}+\zeta \cdot \mathrm{QBO}_{50_{t}}+\eta \cdot \mathrm{SC}_{t} .
$$

Because the tropospheric ozone lifetime approaches a month, the pattern of tropospheric ozone for a month has the 
tendency to persist into the next month. Even after removing the seasonal and other effects in the time series shown in Eq. (1), there is still a month-to-month correlation $(\phi)$ in residuals. This phenomena is called persistence (Wilks, 2011) and is quantified by the degree of autocorrelation of a parameter, shifted by $\mathrm{p}$ time steps (lag $\mathrm{p}$ ). Therefore, the first order autocorrelation of the noise (AR[1]) is included in the model, as explained by Weatherhead et al. (1998).

\section{Tropical tropospheric ozone trends}

For the rest of the discussion about tropical tropospheric ozone, the trend refers to the preferred harmonisation scenario (scenario 1).

\subsection{Tropical distribution of tropospheric $\mathrm{O}_{3}$ trends and mean tropical trend}

Figure 3 summarises the tropical tropospheric ozone trends calculated in a $2.5^{\circ} \times 5^{\circ}$ grid as derived from the preferred merged CCD TTCO dataset using the multivariate regression model (Eq. 1) between 1996 and 2015. As shown in Fig. 3a, the trend varies between -3.2 and 3.7 DU decade ${ }^{-1}$, and the average trend for the period 1996-2015 is statistically notsignificant and equal to $-0.1 \pm 1.2 \mathrm{DU}$ decade $^{-1}(2 \sigma)$. Figure $3 \mathrm{~b}$ shows the $2 \sigma$ of the trend, which is in the order of $\sim 0$ $4 \mathrm{DU}_{\text {decade }}{ }^{-1}$ (mean: 1.2 $\mathrm{DU}_{\text {decade }}{ }^{-1}$ ), with higher values at the tropical borders and values close to zero along the equator. Figure $3 \mathrm{c}$ shows the correlation between the model and the time series. The correlation coefficient reaches 1 over the north and central-east Pacific and the southern Atlantic Ocean. The regions of smaller correlations are mostly over the west Pacific, the Caribbean Sea, Southeast Asia and over the central African continent. The main reason for the low correlation is the weak seasonal cycle observed in these regions. Figure $3 \mathrm{~d}$ shows the RMSE between the time series and the model fit. The RMSE is less than 3 DU close to the equator and reaches $7 \mathrm{DU}$ at the tropical borders. Figure $3 \mathrm{e}$ presents only those grid boxes where the trend is statistically significant and exceeds the maximum difference of the trends calculated from all six scenarios. This additional criterion (to exceed the differences between harmonisation scenarios) allows us to identify grid boxes that have significant trends with higher confidence. Using this stricter criterion, tropospheric ozone trends are positive over some parts of central Africa $\left(\sim 2\right.$ DU decade $\left.^{-1}\right)$, southern Africa and the Atlantic Ocean $\left(\sim 2\right.$ to $\left.3 \mathrm{DU}_{\text {decade }}{ }^{-1}\right)$, India $\left(\sim 2 \mathrm{DUdecade}^{-1}\right)$, and Oceania $\left(\sim 3\right.$ to 4 DU decade $\left.{ }^{-1}\right)$ but are negative over the Caribbean Sea and parts of the North Pacific Ocean $(\sim-2$ to -3 DU decade ${ }^{-1}$ ), as well as over some regions of the southern Pacific Ocean $\left(\sim-2\right.$ DU decade $\left.{ }^{-1}\right)$ seem to be relevant; however, for all other grid boxes trends are highly uncertain and mainly dependent on the choice of the harmonisation scenario. The negative trends appearing in a region at the northern latitudes (Caribbean Sea and northern Pacific) may be an artifact of the dataset (low sampling of data, 54 out of 240 months of data). Finally, Fig. 3f shows the tropical tropospheric ozone trends in per cent per year $\left(\% \mathrm{yr}^{-1}\right)$ that are statistically significant. Here the maximum increase is observed over central Africa $\left(\sim 3 \% \mathrm{yr}^{-1}\right)$; over southern Africa, south tropical Atlantic and Oceania $\left(\sim 1.5 \% \mathrm{yr}^{-1}\right)$; and finally over India and Southeast Asia $\left(\sim 1 \% \mathrm{yr}^{-1}\right)$. The maximum tropospheric ozone decreasing trend is observed over the Caribbean Sea and the northeast tropical Pacific, $\left(\sim-2 \% \mathrm{yr}^{-1}\right)$, followed by the central-south Pacific and Indian oceans, $\sim-1 \% \mathrm{yr}^{-1}$.

The southern and northern boundaries of the tropics $(-15$ to $-20^{\circ} \mathrm{S}$ and 15 to $20^{\circ} \mathrm{N}$ ) are strongly influenced by stratospheric intrusions via tropopause foldings and air masses being transported from the mid-latitudes and the upper troposphere (Pickering et al., 2001; Thompson et al., 2017). Therefore, in order to estimate a more reliable mean trend for the tropics, the multivariate regression model (Eq. 1) has been applied to the mean tropical time series between $-15^{\circ} \mathrm{S}$ and $15^{\circ} \mathrm{N}$. The fit results are shown in Fig. 4. The mean ("global") tropical trend equals $-0.2 \pm 0.6 \mathrm{DU}$ decade $^{-1}$ $(2 \sigma)$. This means that there is no significant trend for tropospheric ozone in the tropics. The mean tropospheric ozone trend is in agreement with Ziemke et al. (2005) (using solar backscatter ultraviolet, SBUV, and Total Ozone Mapping Spectrometer, TOMS, version 8 data from 1979 to 2003) and Ebojie et al. (2016) (using SCIAMACHY limb-nadirmatching, LNM, observations during the period 2003-2011) who also indicated insignificant and near-zero global trends in the tropics, although their analysis was based on different datasets and covered shorter time periods. Nevertheless, Heue et al. (2016), using a similar CCD method on the same period and satellite instruments, reported a significant average increase of $0.7 \pm 0.1 \mathrm{DU}_{\text {decade }}{ }^{-1}$.

The tropical mean tropospheric ozone time series (black stars) shows a seasonal cycle with higher values in JulyOctober. The time series are well represented by the regressed tropospheric ozone (red line) and the residual (orange line in upper panel) is less than 5 DU. The seasonal cycle contributes the most to the TTCO variability in the tropics by about \pm 2 DU. Tropical tropospheric ozone is reduced by 4 DU during El Niño years (1997-1998, 2006-2007, 20092010, 2015) and slightly increases by 1-2 DU during strong La Niña years (1999-2000, 2007-2008, 2010-2011). QBO and the solar cycle, do not contribute to the interannual mean tropical tropospheric ozone variability. Overlaid in black for all proxies are the time series with all fit terms removed except the particular fit parameter. This allows us to relate the magnitude of changes due to a selected process to the observed residuals (or unexplained variations). 


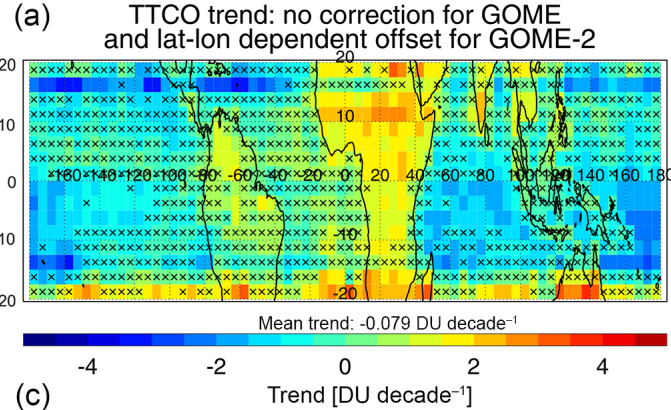

(c)

Correlation $(R)$ between the trend model and the time series

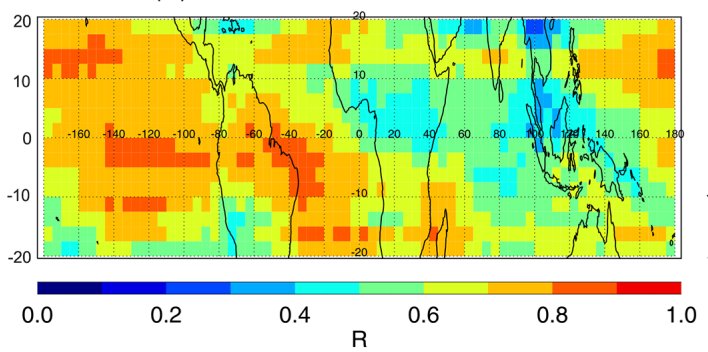

(e)

Significant trend that exceeds the range of all scenarios

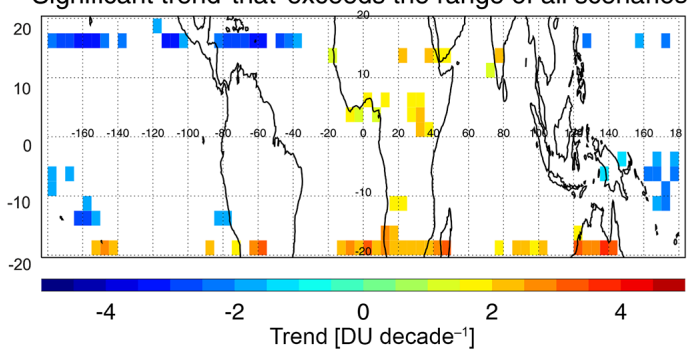

(b)

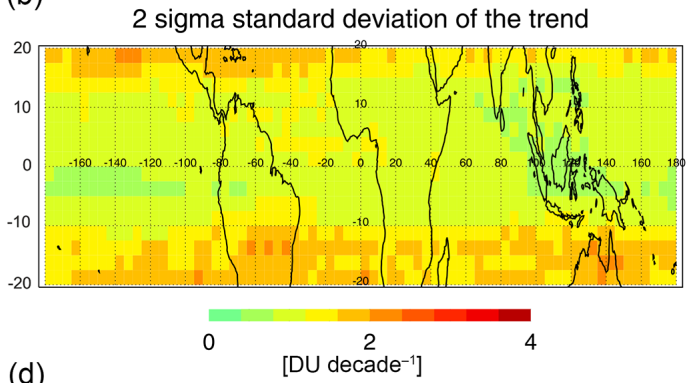

RMSE between the trend model and the time series

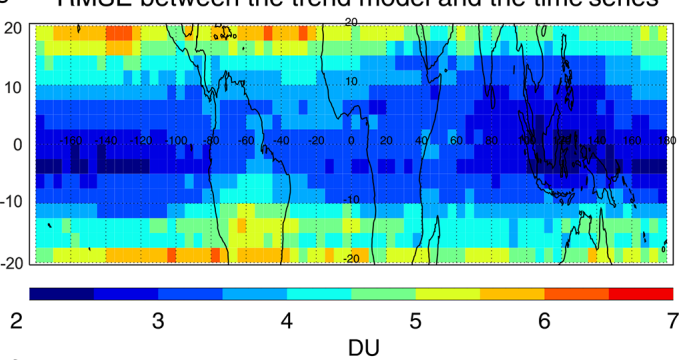

(f)

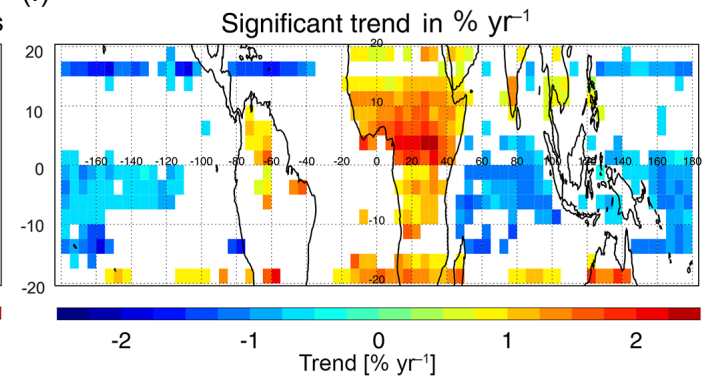

Figure 3. (a) Tropical tropospheric ozone trends using a linear multivariate first order auto-regression model for the selected harmonised scenario 1 in DU decade ${ }^{-1}$. Grid boxes marked with " $x$ " are statistically non-significant at the $95 \%$ confidence level $\left(b>2 \sigma_{\beta}\right)$. (b) $2 \sigma$ standard deviation of the trend. (c) The correlation coefficient, $R$, between the multi-linear trend model fit and the original time series. (d) The RMS between the trend model and the time series. (e) The statistically significant trend that exceeds the maximum absolute difference of the trends calculated for all six scenarios. (f) The significant tropical tropospheric ozone trend in $\% \mathrm{yr}^{-1}$.

\subsection{Regionally averaged tropical tropospheric ozone trends}

We also studied regional trends focusing on the regions where the trends are statistically significant. The TTCO have been regionally averaged for eight regions and the regression analysis applied to them. The following regions are listed. A: the Caribbean Sea $\left(15\right.$ to $17.5^{\circ},-85$ to $\left.-45^{\circ}\right)$, B: India (10 to $20^{\circ}, 70$ to $\left.-85^{\circ}\right), \mathrm{C}$ : northern South America (0 to $10^{\circ},-75$ to $-60^{\circ}$ ), D: north Africa (5 to $15^{\circ},-17.5$ to $50^{\circ}$ ), E: east Pacific Ocean (0 to $7.5^{\circ},-180$ to $\left.-110^{\circ}\right)$, F: Indian Ocean (0 to $7.5^{\circ}, 50$ to $\left.100^{\circ}\right), \mathrm{G}$ : west Pacific Ocean ( 0 to $7.5^{\circ}, 160$ to $\left.180^{\circ}\right)$ and $\mathrm{H}$ : southern Africa ( -20 to $-12.5^{\circ}, 10$ to $\left.50^{\circ}\right)$.

As shown in Fig. 5 and Table 2, regions B, C, D and $\mathrm{H}$ show significant increase of the order of 1-1.5 DU decade ${ }^{-1}$ and regions $\mathrm{A}, \mathrm{E}, \mathrm{F}$, and $\mathrm{G}$ a significant ozone decrease of the order of $1.2-1.9 \mathrm{DU}_{\text {decade }}{ }^{-1}$. The observed significant positive changes in tropospheric $\mathrm{O}_{3}$ over north Africa and
Table 2. Regional tropospheric ozone trends in eight tropical regions. In bold are the regions where the trend is greater than 3 times the standard deviation of the trend $(3 \sigma)$.

\begin{tabular}{lr}
\hline Area & $\begin{array}{r}\text { Tropospheric } \mathrm{O}_{3} \text { trend } \pm 2 \sigma \\
\text { in DU decade }\end{array}$ \\
\hline (A) Caribbean Sea & $-1.59 \pm 1.30$ \\
(B) India & $1.10 \pm 0.86$ \\
(C) northern South America & $0.99 \pm 0.94$ \\
(D) north Africa & $1.54 \pm 1.09$ \\
(E) east Pacific Ocean & $\mathbf{- 1 . 2 1} \pm \mathbf{0 . 6 5}$ \\
(F) Indian Ocean & $\mathbf{- 1 . 6 1} \pm \mathbf{0 . 8 3}$ \\
(G) west Pacific Ocean & $\mathbf{- 1 . 8 7} \pm \mathbf{0 . 7 2}$ \\
(H) southern Africa & $1.44 \pm 1.28$
\end{tabular}




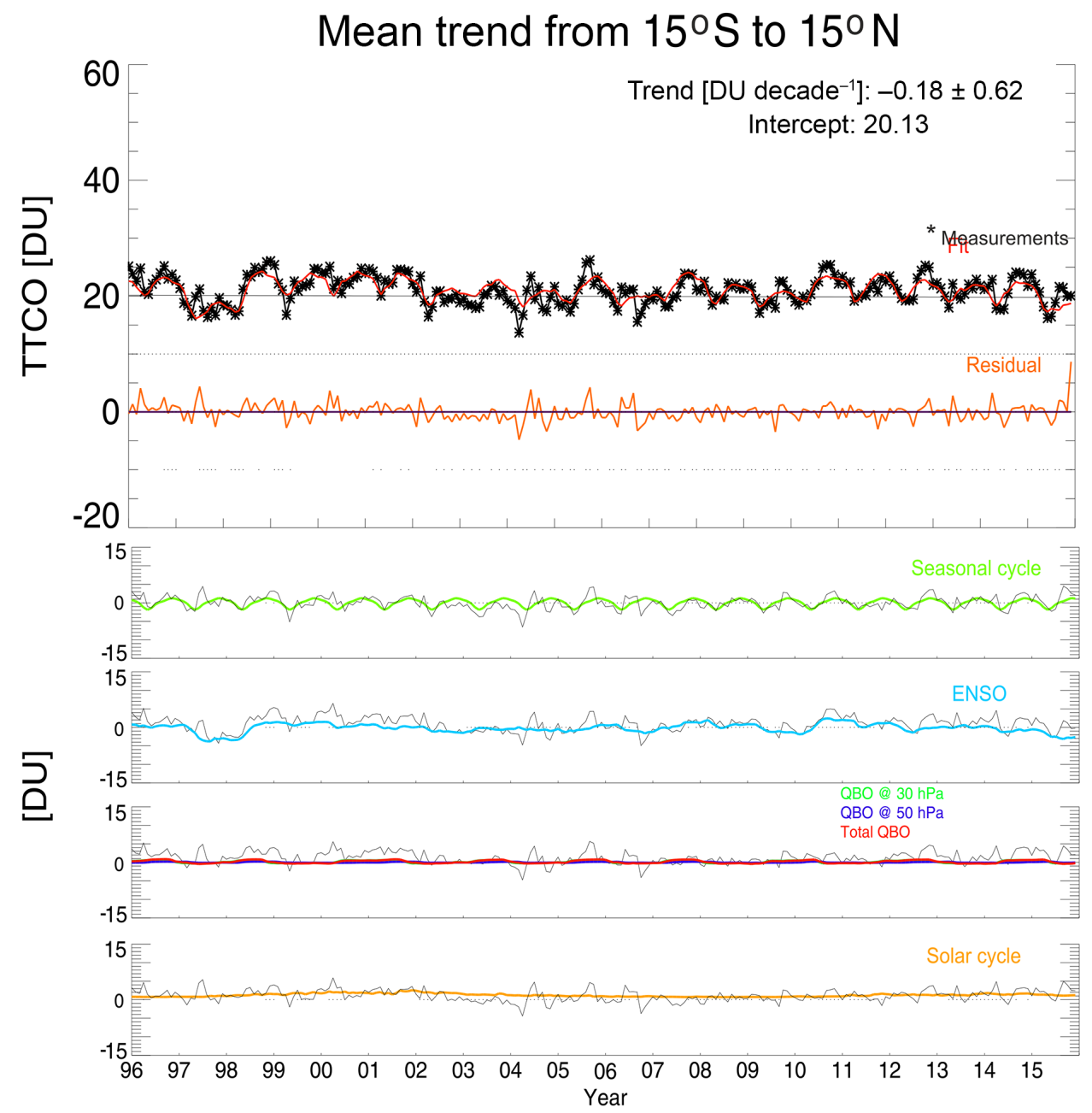

Figure 4. Mean tropical tropospheric ozone trends between $-15^{\circ} \mathrm{S}$ to $15^{\circ} \mathrm{N}$ for the period 1996 to 2015 . Top: the multivariate linear trend (black), the fit (red) and the residual (orange) are plotted. The mean tropical tropospheric ozone trend is equal to -0.18 and the $2 \sigma$ uncertainty in the trend is $\pm 0.62 \mathrm{DU}$ decade ${ }^{-1}$. The next panels show the harmonic functions (green), ENSO (light blue), QBO (red) and solar solar (orange). Overlaid in black for all proxies are the time series with all fit terms removed except the particular fit parameter.

parts of the Arabian sea (D), south Africa and the southern African outflow $(\mathrm{H})$, parts of India (B), and north south America (C) agree well with results of Lelieveld et al. (2004), Beig and Singh (2007), Kulkarni et al. (2010), Ebojie et al. (2016) and Heue et al. (2016) who also observed an increasing ozone trend over these regions. Although, Ebojie et al. (2016) observe a decreasing trend of $-0.5 \mathrm{DU} \mathrm{decade}^{-1}$ in tropospheric ozone over northeast Africa (D).

The negative changes in TTCO over the Caribbean Sea (A) are in agreement with the results of Ebojie et al. (2016). However, the observed trends over the northern and southern tropical latitudes (18 to $20^{\circ}$ in $\mathrm{SH}$ and $\mathrm{NH}$ ) should be generally interpreted with caution because they are influenced by low sampling of data due to the movement of the ITCZ, which reduces the cloudy data during local winters and makes the above-cloud ozone column (ACCO) retrieval difficult, violating in some cases the invariance of the ACCO per latitude band. The decreasing tropospheric ozone trend over the western Pacific $(G)$ and Indian $(F)$ oceans agrees well with Heue et al. (2016). On the other hand, the decreasing trend over the eastern Pacific Ocean (E) is in disagreement with Heue et al. (2016) who reported a significant increase of the order of $0.5-1$ DU decade ${ }^{-1}$.

\subsection{Seasonal tropospheric $\mathrm{O}_{3}$ trends}

Seasonal tropospheric $\mathrm{O}_{3}$ trends can be useful for understanding the connection between the factors (e.g. meteorology or emissions) that contribute to tropospheric ozone changes and its distribution. For this reason, the multi-linear regression model has been applied to monthly time series containing only the following months: December-February, March-May, June-August and September-November. For these time series no seasonal terms are used in the regres- 


\section{Trop $\mathrm{O}_{3}$ column trend}
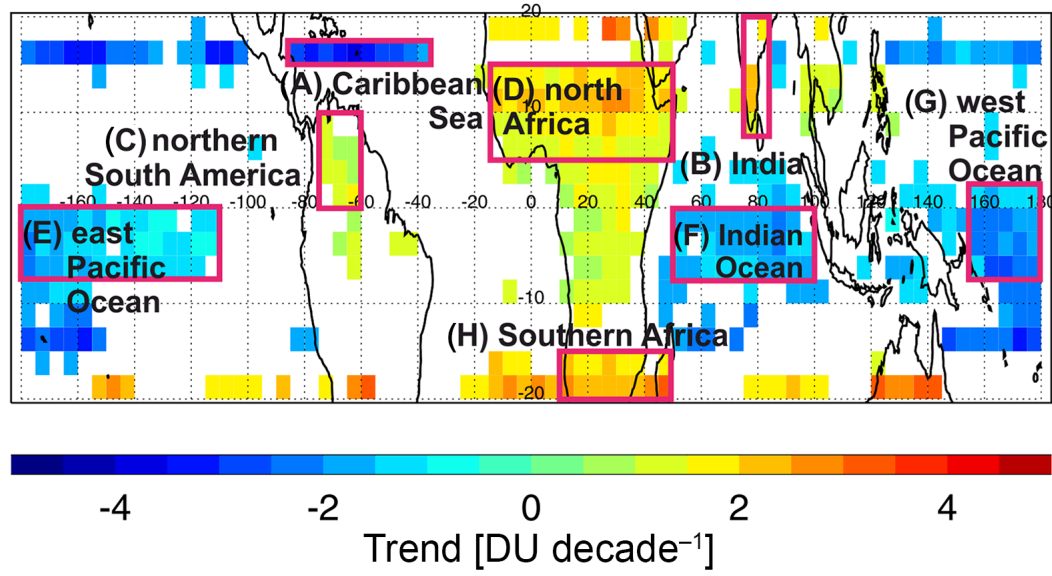

(A) CARIBBEAN SEA
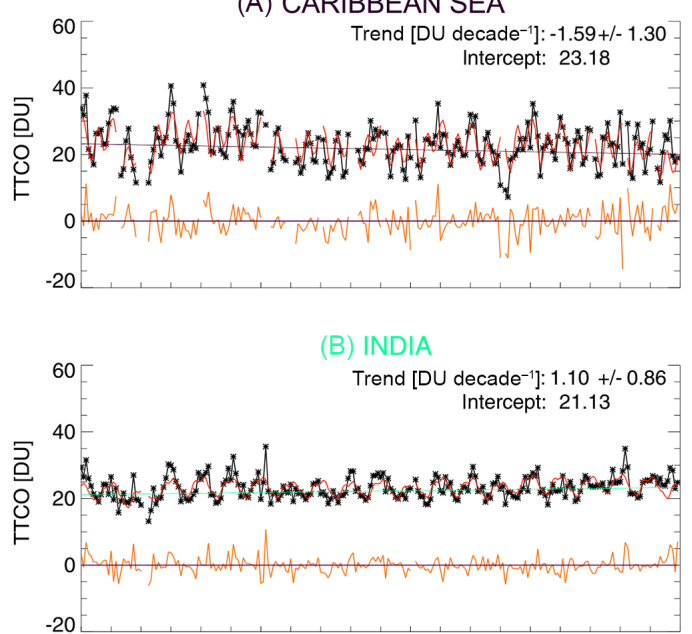

(C) NORTH SOUTH AMERICA
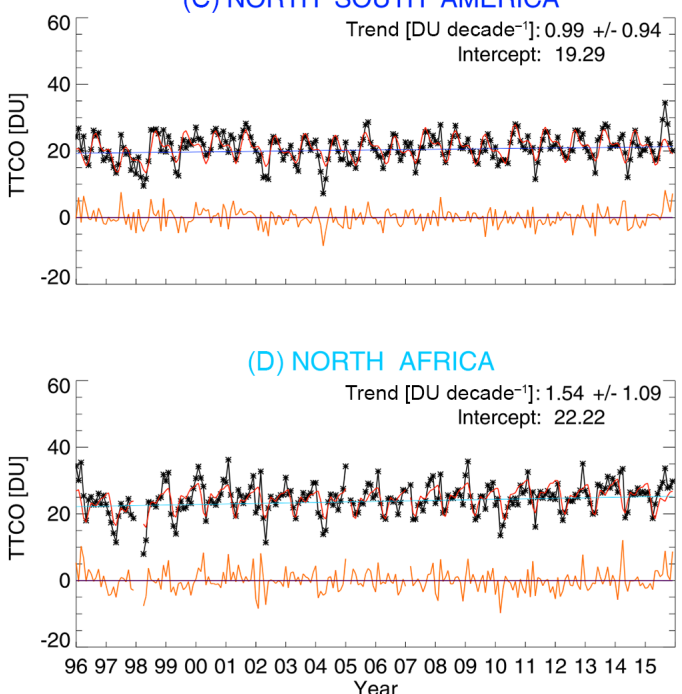
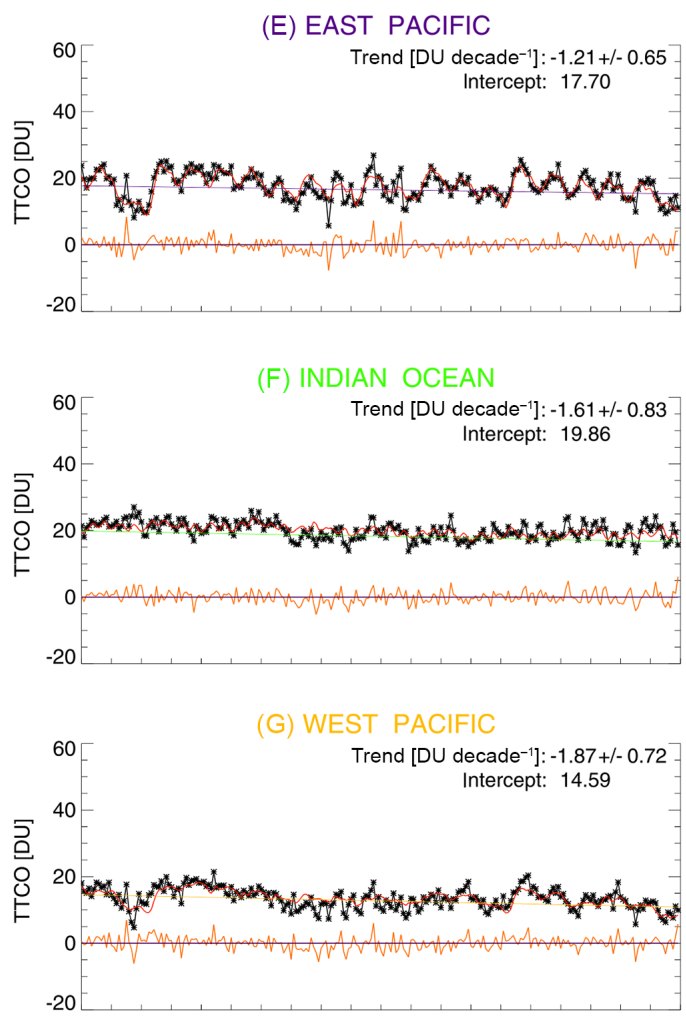

(H) SOUTH AFRICA

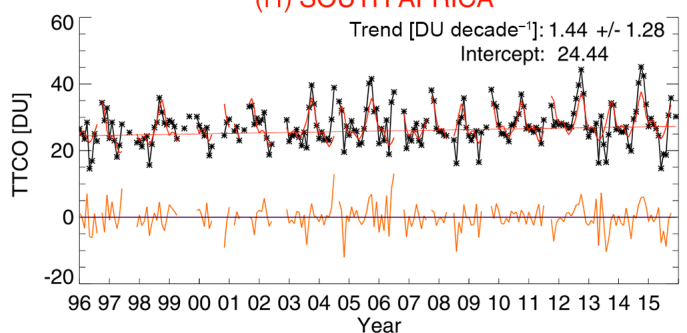

Figure 5. Tropical tropospheric ozone trend in (A) Caribbean Sea, (B) India, (C) northern South America, (D) north Africa, (E) east Pacific Ocean, (F) Indian Ocean, $(\mathbf{G})$ west Pacific Ocean and $(\mathbf{H})$ southern Africa. 

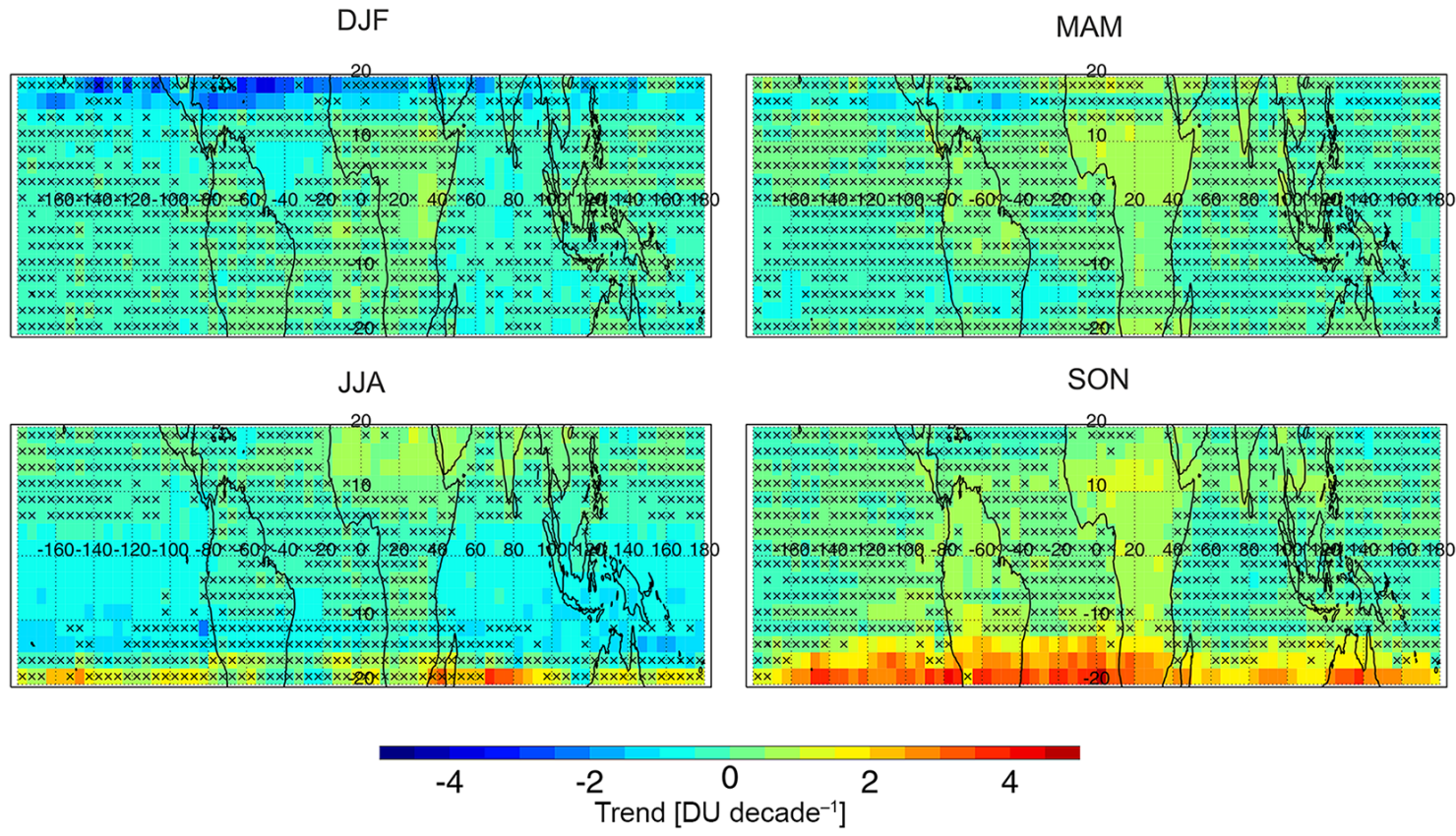

Figure 6. Tropical tropospheric ozone trends for winter (DJF), spring (MAM), summer (JJA) and autumn (SON) for the years 1996 to 2015. Black " $x$ " denote statistically non-significant trend.

sion. In Fig. 6, the maximum decreasing trends appear during December to February over the northern tropical Atlantic and Pacific oceans $\left(\sim-4 \mathrm{DU}_{\text {decade }}{ }^{-1}\right)$. These air masses are more affected by changes occurring in the midlatitudes due to the southward movement of the ITCZ in these months and the strong westerly air flow over the tropical borders (Oltmans et al., 2004). Therefore, it is possible that changes in ozone precursors, such as $\mathrm{NO}_{2}$ over North America and Europe may have affected the $\mathrm{O}_{3}$ trends over these tropical latitudes (Logan et al., 2012; Hilboll et al., 2013b). This decrease might also be associated with the limited number of TTCO measurements on the northern tropical borders, thus it demands a more careful investigation. The trends are mostly insignificant between March and May, with the exception of Africa where ozone is increasing by $\sim 1$ DU decade ${ }^{-1}$ and some parts over South America where ozone is decreasing by less than $1 \mathrm{DU}$ decade $^{-1}$. During June to August, ozone shows a small statistically significant decrease over the Pacific and Indian oceans (12 DU decade ${ }^{-1}$ ). Possible reasons for tropospheric ozone decrease over the oceans may be related to changes in sea surface temperatures, which are closely tied to the tropospheric humidity (Trenberth, 2011; IPCC, 2007). As discussed earlier,the production of $\mathrm{HO}_{x}\left(\mathrm{OH}\right.$ and $\left.\mathrm{HO}_{2}\right)$ from water vapour in the troposphere accounts for one of the most important sinks of tropospheric ozone (Jacob, 2000). An increase in vertical convective patterns over the tropical oceans may result in lower ozone mixing ratios in the upper troposphere where the WFDOAS (weighting function differential optical absorption spectroscopy) retrieval is more sensi- tive (Morris et al., 2010; Wai et al., 2014; Fontaine et al., 2011; Ziemke et al., 2009a; Coldewey-Egbers et al., 2005). Several studies have shown that the total column of water vapour (TCWV) has increased over the tropics. Mieruch et al. (2014) and Trenberth et al. (2005) found that the TCWV has increased by $\sim 1-2 \%$ decade $^{-1}$ over the oceans. Chen and Liu (2016) also found that the precipitable water vapour (PWV) increased by $1-2 \%$ in the tropics between 1992-2014. The precipitation increase is about $4 \%$ over the ocean, while a decrease of $2 \%$ is found over land in the latitude range $-25^{\circ} \mathrm{S}$ to $25^{\circ} \mathrm{N}$, between 1979 and 2001 (Adler et al., 2003). The significant positive trend of ozone at the southern tropical Atlantic, southern Africa, South America and Oceania maximise during September to November $\left(\sim 4\right.$ DU decade $\left.{ }^{-1}\right)$. According to MODIS/TERRA fire radiative power $\left(\mathrm{mW} \mathrm{m}^{-2}\right)$ data (https://disc.gsfc.nasa.gov/ neespi/data-holdings $/ \bmod 14 \mathrm{~cm} 1 . \mathrm{shtml}$ ) boreal autumn is the season with the most intense fires over southern Africa and South America. The burned area in southern tropical Africa increased by $1.8 \% \mathrm{yr}^{-1}$ during the period 2000 to 2011 Giglio et al. (2013). Ziemke et al. (2009b) and Wai et al. (2014) estimated that biomass burning can contribute to an increase in tropospheric ozone column by $\sim 20 \%$. Hence, it is very likely that biomass burning could be the origin of the observed ozone increase. 


\section{Summary and discussion}

The new harmonised dataset of tropical tropospheric ozone columns for the last 20 years between 1996 and 2015 makes it possible to calculate and study long-term tropospheric $\mathrm{O}_{3}$ variability and trends. Correction offsets have been calculated for GOME and GOME-2 TTCO using SCIAMACHY as reference (in the middle of the time series) in order to reduce the instrumental effects in the long-term time series. Nevertheless, the short overlap period between GOME and SCIAMACHY limits the harmonisation of the GOME dataset. The correction offsets for GOME presented artificial features which are also visible afterwards in the trend (see Fig. S1 in the Supplement). In order to identify the best way to merge the CCD data and also to investigate how the harmonisation approach may affect the observed trends, six different harmonisation scenarios have been evaluated by comparing with ozonesondes. The merging scenario, using no correction for GOME (short overlap) and the mean bias correction of GOME-2 with respect to SCIAMACHY in each grid box, was found to show slightly smaller differences to ozonesondes, and therefore was considered to be the preferred scenario. From the trend analysis of all merged datasets, a rough estimate of the variability in trends due to merging approaches was provided $\left(\sim \pm 2 \mathrm{DU} \mathrm{decade}^{-1}\right)$. After the harmonisation, the data obtained from the different instruments agree better with each other and with ozonesondes.

Harmonisation and merging of multi-instrument datasets is one of the largest sources of uncertainty. Most of the trend studies that use multiple satellite data (e.g. Xu et al., 2011, Loyola et al., 2009, Heue et al., 2016, and TOAR) do not account for uncertainties related to the merging approach. Therefore, in order to quantify the uncertainty due to harmonisation, multi-linear tropospheric ozone trends using all six harmonised datasets have been derived and the maximum deviation between them has been calculated. The trends range between about -4 and $4 \mathrm{DU}$ decade $^{-1}$ and the average difference between the trends from the six scenarios has been found to be $\sim 2 \mathrm{DU}$ decade $^{-1}$, locally exceeding the $2 \sigma$ of the individual trends ( 0 to $4 \mathrm{DU}$ decade $^{-1}$ ). We conclude that the overall uncertainties in the trends are larger than the statistical ones reported.

Despite the fact that the trend results using the preferred merged dataset are small $\left(< \pm 4 \mathrm{DU}\right.$ decade $^{-1}$ or $\left.3 \% \mathrm{yr}^{-1}\right)$ and mostly uncertain (66\% are statistically insignificant), there are regions such as over southern Africa, the southern tropical Atlantic, southeast tropical Pacific Ocean and central Oceania where tropospheric $\mathrm{O}_{3}$ increased significantly by $\sim 3 \mathrm{DU} \mathrm{decade}^{-1}$. In central Africa and southern India, tropospheric ozone increased by $\sim 2 \mathrm{DU}$ decade $^{-1}$. Regional positive tropospheric ozone trends of similar magnitude were also observed in other studies (e.g. Lelieveld et al., 2004; Beig and Singh, 2007; Kulkarni et al., 2010; Cooper et al., 2014; Ebojie et al., 2016; Heue et al., 2016). On the other hand, tropospheric $\mathrm{O}_{3}$ decreases by $\sim 3$ DU decade ${ }^{-1}$ over the Caribbean Sea and parts of the North Pacific Ocean, and by less than $2 \mathrm{DU}$ decade $^{-1}$ over some regions of the southern Pacific Ocean. The most important limitation in interpreting the observed trends over the northern and southern tropical latitudes $\left(18-20^{\circ}\right.$ in $\mathrm{SH}$ and $\left.\mathrm{NH}\right)$ is the low data sampling at these latitudes. Due to the ITCZ movement, cloudy data during local winters are reduced, making the ACCO retrieval difficult or violating the invariance of the ACCO per latitude band. Therefore, even though they might appear to be statistically significant, they should be referred to with caution.

The mean tropospheric ozone trend has been estimated between $-15^{\circ} \mathrm{S}$ and $15^{\circ} \mathrm{N}$ during the period 1996-2015. This restriction has been applied in order to avoid the influence of subtropical air masses on tropospheric ozone abundances at the tropical borders (Thompson et al., 2017). The mean trend for global tropics $\left(-15^{\circ} \mathrm{S}-15^{\circ} \mathrm{N}\right)$ is found to be almost equal to zero $\left(-0.2 \pm 0.6 \mathrm{DU}\right.$ decade $\left.^{-1}\right)$ and statistically non-significant. This is in agreement with studies of Ziemke et al. (2005) (nearly zero trend) and Ebojie et al. (2016) $\left(0.3 \pm 0.4 \% \mathrm{yr}^{-1}\right.$ for the southern tropics and $0.1 \pm 0.5 \% \mathrm{yr}^{-1}$ for the northern tropics) who also found no trend or insignificant trends. This is in contrast with the results of Heue et al. (2016) who found a mean increase of $0.7 \pm 0.1 \mathrm{DU}$ decade $^{-1}$ for the entire tropics.

Comparison of several independent studies conducted on tropospheric ozone trends shows that the trends vary in sign and magnitude for the past few decades in the tropics (Cooper et al., 2014; Ziemke et al., 2005; Monks et al., 2015; Oltmans et al., 2013; Lelieveld et al., 2004; Lin et al., 2014; Beig and Singh, 2007; Kulkarni et al., 2010; Thompson et al., 2014; Heue et al., 2016; Ebojie et al., 2016). This is a significant issue for the scientific community, especially climate modelers who try to use recent past data to evaluate the performance of climate and global atmospheric chemistry models for future prediction (Zhang et al., 2016; Young et al., 2018). At the moment, there is a new activity of the International Global Atmospheric Chemistry project (IGAC), named Tropospheric Ozone Assessment Report (TOAR), which aims to assess our knowledge of the tropospheric ozone distribution, pattern and trends, using the available surface ozone data, ozone sonde, aircraft and satellite observations (currently under review in Elementa: https://collections.elementascience.org/toar/).

The accurate interpretation of the trend results is challenging and requires the parallel investigation of changes in numerous factors that impact on ozone production, loss and transport in the troposphere, including various feedbacks (e.g. Cooper et al., 2014, and references therein). Finally, the attribution of observed TTCO trends in specific regions to the various processes is not possible without the additional use of chemistry transport models that can potentially disentangle the different contributions to tropospheric ozone variability (dynamics and chemistry; Grewe et al., 2012; Coates et al., 2015). 
The launch of the Sentinel-5 precursor (S5p) satellite in 2017 and the planned launches of three consecutive Sentinel5 instruments until 2030 will extend the TTCO record which will likely result in more reliable trends. The grid-box size used in this study was relatively coarse $\left(2.5^{\circ} \times 5^{\circ}\right)$, due to the instruments spatial resolution (GOME pixel $\simeq 320 \mathrm{~km}$ ) and in order to remove the residual noise. The high spatial resolution $(7 \mathrm{~km} \times 7 \mathrm{~km})$ of the TROPOspheric Monitoring Instrument (TROPOMI) instrument aboard S5p will improve the trend estimates of tropospheric ozone in particular over mega-cities.

Data availability. Data used in this publication can be accessed via the IUP website: http://www.iup.uni-bremen.de/UVSAT/datasets/ tropospheric-ozone-ccd or by contacting Mark Weber (weber@unibremen.de).

\section{The Supplement related to this article is available online at https://doi.org/10.5194/acp-18-9189-2018-supplement.}

Competing interests. The authors declare that they have no conflict of interest.

Acknowledgements. We thank the two reviewers for their helpful comments and suggestions. This study was supported in parts by the DLR S5P project (50EE1247 and 50EE1618) and the federal state of Bremen.

The article processing charges for this open-access publication were covered by the University of Bremen.

Edited by: Yugo Kanaya

Reviewed by: Gary Morris and one anonymous referee

\section{References}

Adler, F. R., Huffman, G. J., Chang, A., Ferraro, R., Xie, P. P., Janowiak, J., Rudolf, B., Schneider, B. U., Curtis, S., Bolvin, D., Gruber, A., Susskind, J., Arkin, P., and Nelkin, E.: The version-2 Global Precipitation Climatology Project (GPCP) monthly precipitation analysis (1979-present), J. Hydrometeorol., 4, 11471167, 2003.

Beig, G. and Singh, V.: Trends in tropical tropospheric column ozone from satellite data and MOZART model, Geophys. Res. Lett., 34, L17801, https://doi.org/10.1029/2007GL030460, 2007.

Bovensmann, H., Burrows, J. P., Buchwitz, M., Frerick, J., Noël, S., Rozanov, V. V., Chance, K. V., and Goede, A. P. H.: SCIAMACHY: Mission Objectives and Measurement Modes, J. Atmos. Sci., 56, 127-150, https://doi.org/10.1175/15200469(1999)056<0127:SMOAMM>2.0.CO;2, 1999.
Burrows, J. P., Hölzle, E., Goede, A., Visser, H., and Fricke, W.: SCIAMACHY - scanning imaging absorption spectrometer for atmospheric chartography, Ac. Astronaut., 35, 445-451, 1995.

Burrows, J. P., Weber, M., Buchwitz, M., Rozanov, V., Ladstätter-Weißenmayer, A., Richter, A., DeBeek, R., Hoogen, R., Bramstedt, K., Eichmann, K.-U., Eisinger, M., and Perner, D.: The Global Ozone Monitoring Experiment (GOME): Mission Concept and First Scientific Results, J. Atmos. Sci., 56, 151-175, https://doi.org/10.1175/15200469(1999)056<0151:TGOMEG>2.0.CO;2, 1999.

Callies, J., Corpaccioli, E. and Eisinger, M., Hahne, A., and Lefebvre, A.: GOME-2 - Metop-s second-generation sensor for operational ozone monitoring, ESA Bull. Sp. Agency, 102, 28-36, 2000.

Chameides, W. L. and Walker, J. C. G.: A photochemical theory for tropospheric ozone, J. Geophys. Res., 78, 8751-8760, 1973.

Chandra, S., Ziemke, J. R., Tie, X., and Brasseur, G.: Elevated ozone in the troposphere over the Atlantic and Pacific oceans in the Northern Hemisphere, Geophys. Res. Lett., 31, L23102, https://doi.org/10.1029/2004GL020821, 2004.

Chandra, S., Ziemke, J. R., Duncan, B. N., Diehl, T. L., Livesey, N. J., and Froidevaux, L.: Effects of the 2006 El Niño on tropospheric ozone and carbon monoxide: implications for dynamics and biomass burning, Atmos. Chem. Phys., 9, 4239-4249, https://doi.org/10.5194/acp-9-4239-2009, 2009.

Chen, B. and Liu, Z.: Global water vapor variability and trend from the latest 36 year (1979 to 2014) data of ECMWF and NCEP reanalyses, radiosonde, GPS, and microwave satellite, J. Geophys. Res.-Atmos., 121, 11442-11462, https://doi.org/10.1002/2016JD024917, 2016.

Coates, J. and Butler, T. M.: A comparison of chemical mechanisms using tagged ozone production potential (TOPP) analysis, Atmos. Chem. Phys., 15, 8795-8808, https://doi.org/10.5194/acp15-8795-2015, 2015.

Coldewey-Egbers, M., Weber, M., Lamsal, L. N., de Beek, R., Buchwitz, M., and Burrows, J. P.: Total ozone retrieval from GOME UV spectral data using the weighting function DOAS approach, Atmos. Chem. Phys., 5, 1015-1025, https://doi.org/10.5194/acp-5-1015-2005, 2005.

Cooper, O. R., Parrish, D. D., Stohl, A., Trainer, M., Néd'elec, P., Thouret, V., Cammas, J. P., Oltmans, S. J., Johnson, B. J., Tarasick, D., Leblanc, T., McDermid, I. S., Jaffe, D., Gao, R., Stith, J., Ryerson, T., Aikin, K., Campos, T., Weinheimer, A., and Avery, M. A.: Increasing springtime ozone mixing ratios in the free troposphere over western North America, Nature, 463, 344-348, 2010.

Cooper, O. R., Parrish, D. D., Ziemke, J., Balashov, N. V., Cupeiro, M., Galbally, I. E., Gilge, S., Horowitz, L., Jensen, N. R., Lamarque, J.-F., Naik, V., Oltmans, S. J., Schwab, J., Shindell, D. T., Thompson, A. M., Thouret, V., Wang, Y., and Zbinden, R. M.: Global distribution and trends of tropospheric ozone: An observation-based review, Elem. Sci. Anthr., 2, 000029, https://doi.org/10.12952/journal.elementa.000029, 2014.

Crutzen, P. J.: The influence of nitrogen oxides on the atmospheric ozone content, Q. J. Roy. Meteorol. Soc., 96, 320-325, 1970.

Crutzen, P. J.: Geology of mankind: the anthropocene, Nature, 415 , p. 23, 2002.

Dahlmann, K., Grewe, V., Ponater, M., and Matthes, S.: Quantifying the contributions of individual $\mathrm{NO}_{x}$ sources to the trend 
in ozone radiative forcing, Atmos. Environ. 45, 2860-2868. https://doi.org/10.1016/j.atmosenv.2011.02.071, 2011

Derwent, R. G., Jenkin, M. E., Saunders, S. M., Pilling, M. J., Simmonds, P. G., Passant, N. R., Dollard, G. J., Dumitrean, P., and Kent, A.: Photochemical ozone formation in northwest Europe and its control, Atmos. Environ., 37, 1983-1991, 2003.

Diab, R. D., Raghunandan, A., Thompson, A. M., and Thouret, V.: Classification of tropospheric ozone profiles over Johannesburg based on mozaic aircraft data, Atmos. Chem. Phys., 3, 713-723, https://doi.org/10.5194/acp-3-713-2003, 2003.

Dickerson, R. R., Rhoads, K. P., Carsey, T. P., Oltmans, S. J., Burrows, J. P., and Crutzen, P. J.: Ozone in the remote marine boundary layer: A possible role for halogens, J. Geophys. Res., 104, 21385-21395, https://doi.org/10.1029/1999JD900023, 1999.

Doughty, D. C., Thompson, A. M., Schoeberl, M. R., Stajner, I., Wargan, K., and Hui, W. C. J.: An intercomparison of tropospheric ozone retrievals derived from two Aura instruments and measurements in western North America in 2006, J. Geophys. Res., 116, D06303, https://doi.org/10.1029/2010JD014703, 2011

Duncan, B. N., Yoshida, Y., Olson, J. R., Sillman, S., Martin, R. V., Lasmal, L., Hu, Y., Pickering, K. E., Retscher, C., Allen, D. J., and Crawford, J. H.: Application of OMI observations to a spacebased indicator of $\mathrm{NO}_{x}$ and VOC controls on surface ozone formation, Atmos. Environ., 44, 2213-2223, 2010.

Duncan, B. N., Lamsal, L. N., Thompson, A. M., Yoshida, Y., Lu, Z., Streets, D. G., Hurwitz, M. M., and Pickering, K. E.: A space-based, high-resolution view of notable changes in urban $\mathrm{NO}_{x}$ pollution around the world (2005-2014), J. Geophys. Res.Atmos., 121, 976-996, https://doi.org/10.1002/2015JD024121, 2016.

Ebojie, F., von Savigny, C., Ladstätter-Weißenmayer, A., Rozanov, A., Weber, M., Eichmann, K., Bötel, S., Rahpoe, N., Bovensmann, H., and Burrows, J. P.: Tropospheric column amount of ozone retrieved from SCIAMACHY limb/nadirmatching observations, Atmos. Meas. Tech., 7, 2073-2096, https://doi.org/10.5194/amt-7-2073-2014, 2014.

Ebojie, F., Burrows, J. P., Gebhardt, C., Ladsttter-Weienmayer, A., von Savigny, C., Rozanov, A., Weber, M., and Bovensmann, H.: Global tropospheric ozone variations from 2003 to 2011 as seen by SCIAMACHY, Atmos. Chem. Phys., 16, 417-436, https://doi.org/10.5194/acp-16-417-2016, 2016.

Fishman, J. and Larsen, J. C.: Distribution of total ozone and stratospheric ozone in the tropics: Implications for the distribution of tropospheric ozone, J. Geophys. Res., 92, 6627-6634, 1987.

Fishman, J., Watson, C. E., Larsen, J. C., and Logan, J. A.: Distribution of tropospheric ozone determined from satellite data, J. Geophys. Res., 95, 3599-3617, https://doi.org/10.1029/JD095iD04p03599, 1990.

Fontaine, B., Roucou, P., Gaetani, M., and Marteau, R.: Recent changes in precipitation, ITCZ convection and northern tropical circulation over North Africa (1979-2007), Int. J. Climatol., 31, 633-648, https://doi.org/10.1002/joc.2108, 2011.

Grenfell, J. L., Shindell, D. T., and Grewe, V.: Sensitivity studies of oxidative changes in the troposphere in 2100 using the GISS GCM, Atmos. Chem. Phys., 3, 1267-1283, https://doi.org/10.5194/acp-3-1267-2003.

Grewe, V., Dameris, M., Hein, R., Sausen, R., and Steil, B.: Future changes of the atmospheric composition and the impact of climate change, Tellus, 53B, 103-121, https://doi.org/10.1034/j.1600-0889.2001.d01-10.x, 2001.

Grewe, V., Dahlmann, K., Matthes, S., and Steinbrecht, W.: Attributing ozone to $\mathrm{NO}_{x}$ emissions: Implications for climate mitigation measures, Atmos. Environ., 59, 102-107, https://doi.org/10.1016/j.atmosenv.2012.05.002, 2012.

Giglio, L., Randerson, J. T., and van der Werf, G. R.: Analysis of daily, monthly, and annual burned area using the fourth generationglobal fire emissions database (GFED4), J. Geophys. Res.Biogeol., 118, 317-328, https://doi.org/10.1002/jgrg.20042, 2013

Hauglustaine, D. A., Lathière, J., Szopa, S., and Folberth, G. A.: Future tropospheric ozone simulated with a climatechemistry-biosphere model, Geophys. Res. Lett., 32, L24807, https://doi.org/10.1029/2005GL024031, 2005.

Heue, K.-P., Coldewey-Egbers, M., Delcloo, A., Lerot, C., Loyola, D., Valks, P., and van Roozendael, M.: Trends of tropical tropospheric ozone from 20 years of European satellite measurements and perspectives for the Sentinel-5 Precursor, Atmos. Meas. Tech., 9, 5037-5051, https://doi.org/10.5194/amt-9-50372016, 2016.

Hilboll, A., Richter, A., and Burrows, J. P.: Long-term changes of tropospheric $\mathrm{NO}_{2}$ over megacities derived from multiple satellite instruments, Atmos. Chem. Phys., 13, 4145-4169, https://doi.org/10.5194/acp-13-4145-2013, 2013b

Hilboll, A., Richter, A., and Burrows, J. P.: $\mathrm{NO}_{2}$ pollution over India observed from space - the impact of rapid economic growth, and a recent decline, Atmos. Chem. Phys. Discuss., https://doi.org/10.5194/acp-2017-101, in review, 2017.

Holton, J. R. and Lelieveld, J.: Stratosphere-Troposphere Exchange and its role in the budget of tropospheric ozone, in: Clouds, Chemistry and Climate, edited by: Crutzen, P. J. and Ramanathan V., NATO ASI Series (I: Global Environmental Change), vol 35, Springer, Berlin, Heidelberg, 1996.

Hwang, S.-H., Kim, J., Won, Y.-I., Cho, H. K., Kim, J. S., Lee, D.H., Cho, G.-R., and Oh, S. N.: Statistical characteristics of secondary ozone density peak observed in Korea, Adv. Space Res., 36, 952-957, https://doi.org/10.1016/j.asr.2005.05.080, 2005.

IPCC Working Group 1, I., Stocker, T. F., Qin, D., Plattner, G.K., Tignor, M., Allen, S. K., Boschung, J., Nauels, A., Xia, Y., Bex, V., and Midgley, P. M.: IPCC, 2013: Climate Change 2013: The Physical Science Basis. Contribution of Working Group I to the Fifth Assessment Report of the Intergovernmental Panel on Climate Change, IPCC, Cambridge University Press, Cambridge, UK and New York, NY, USA, AR5, 1535 pp., https://doi.org/10.1017/CBO9781107415324, 2013.

IPCC Climate Change 2007: The Physical Science Basis, Contribution of Working Group I to the Fourth Assessment Report of the IPCC (ISBN 9780521 88009-1 Hardback; 9780521 70596-7 Paperback) Cambridge Univ. Press, 2007.

IUP: http://www.iup.uni-bremen.de/UVSAT/datasets/ tropospheric-ozone-ccd, last access: 19 June 2018.

Jacob, D. J.: Introduction to Atmospheric Chemistry, Princeton University Press, 200-230, 2000.

Jensen, A. A., Thompson, A. M., and Schmidlin, F. J.: Classification of Ascension Island and Natal ozonesondes using self-organizing maps, J. Geophys. Res.-Atmos., 117, D04302, https://doi.org/10.1029/2011jd016573, 2012. 
Kim, J. H., Hudson, R. D., and Thompson, A. M.: A new method of deriving time-averaged tropospheric column ozone over the tropics using total ozone mapping spectrometer (TOMS) radiances: Intercomparison and analysis using TRACE A data, J. Geophys. Res., 101, 24317-24330, 1996.

Kulkarni, P. S., Ghude, S. D., and Bortoli, D.: Tropospheric ozone (TOR) trend over three major inland Indian cities: Delhi, Hyderabad and Bangalore, Ann. Geophys., 28, 1879-1885, https://doi.org/10.5194/angeo-28-1879-2010, 2010.

Leventidou, E., Eichmann, K.-U., Weber, M., and Burrows, J. P.: Tropical tropospheric ozone columns from nadir retrievals of GOME-1/ERS-2, SCIAMACHY/Envisat, and GOME-2/MetOp-A (1996-2012), Atmos. Meas. Tech., 9, 34073427, https://doi.org/10.5194/amt-9-3407-2016, 2016.

Lelieveld, J., van Aardenne, J., Fischer, H., de Reus, M., Williams, J., and Winkler, P.: Increasing ozone over the Atlantic Ocean, Science, 304, 1483-1487, 2004.

Lelli, L., Kokhanovsky, A. A., Rozanov, V. V., Vountas, M., and Burrows, J. P.: Linear trends in cloud top height from passive observations in the oxygen A-band, Atmos. Chem. Phys., 14, 56795692, https://doi.org/10.5194/acp-14-5679-2014, 2014.

Levy II, H.: Normal atmosphere: Large radical and formaldehyde concentrations predicted, Science, 173, 141-143, 1972.

Lin, M., Horowitz, L. W., Oltmans, S. J., Fiore, A. M., and Fan, S.: Tropospheric ozone trends at Mauna Loa Observatory tied to decadal climate variability, Nat. Geosci., 7, 136-143, https://doi.org/10.1038/ngeo2066, 2014.

Logan, J. A., Staehelin, J., Megretskaia, I. A., Cammas, J.P., Thouret, V., Claude, H., De Backer, H., Steinbacher, M., Scheel, H.-E.,Stübi, R., Fröhlich, M., and Derwent, R.:, Changes in ozone over Europe: Analysis of ozone measurements from sondes, regular aircraft (MOZAIC) and alpine surface sites, J. Geophys. Res., 117, D09301, https://doi.org/10.1029/2011JD016952, 2012.

Loyola, D. G., Coldewey-Egbers, M., Zimmer, W., Koukouli, M., Balis, D., Lerot, C., Van Roozendael, M., and Dameris, M.: Total Ozone Trends Derived From The 14-Years Merged Gome/Sciamachy/Gome-2 Data Record, Proceedings: Proc. Atmospheric Science Conference, Barcelona, Spain, 7-11 September 2009 (ESA SP-676, November 2009), 2009.

Mieruch, S., Schröder, M., Noël, S., and Schulz, J.: Comparison of decadal global water vapor changes derived from independent satellite time series, J. Geophys. Res.-Atmos., 119, 1248912499, https://doi.org/10.1002/2014JD021588, 2014.

Mieruch, S., Noël, S., Bovensmann, H., and Burrows, J. P.: Analysis of global water vapour trends from satellite measurements in the visible spectral range, Atmos. Chem. Phys., 8, 491-504, https://doi.org/10.5194/acp-8-491-2008, 2008.

Monks, P. S., Archibald, A. T., Colette, A., Cooper, O., Coyle, M., Derwent, R., Fowler, D., Granier, C., Law, K. S., Mills, G. E., Stevenson, D. S., Tarasova, O., Thouret, V., von Schneidemesser, E., Sommariva, R., Wild, O., and Williams, M. L.: Tropospheric ozone and its precursors from the urban to the global scale from air quality to short-lived climate forcer, Atmos. Chem. Phys., 15, 8889-8973, https://doi.org/10.5194/acp-15-8889-2015, 2015.

Morris, G. A., Thompson, A. M., Pickering, K. E., Chen, S., Bucsela, E. J., and Kucera, P. A.: Observations of ozone production in a dissipating tropical convective cell during TC4, Atmos. Chem.
Phys., 10, 11189-11208, https://doi.org/10.5194/acp-10-111892010, 2010.

Neu, J. L., Flury, T., Manney, G. L., Santee, M. L., Livesey, N. J., and Worden, J.: Tropospheric ozone variations governed by changes in stratospheric circulation, Nat. Geosci., 7, 340-344, https://doi.org/10.1038/ngeo2138, 2014

Ojha, N., Pozzer, A., Akritidis, D., and Lelieveld, J.: Secondary ozone peaks in the troposphere over the Himalayas, Atmos. Chem. Phys., 17, 6743-6757, https://doi.org/10.5194/acp-176743-2017, 2017.

Oltmans, S. J., Johnson, B. J., Harris, J. M., Thompson, A. M., Liu, H. Y., Chan, C. Y., Voemel, H., Fujimoto, T., Brackett, V. G., Chang, W. L., Chen, J.-P., Kim, J. H., Chan, L. Y., and Chang, H.-W.: Tropospheric ozone over the North Pacific from ozonesonde observations, J. Geophys. Res., 109, D15S01, https://doi.org/10.1029/2003JD003466, 2004.

Oltmans, S., Lefohn, A., Shadwick, D., Harris, J., Scheel, H., Galbally, I., Tarasick, D., Johnson, B., Brunke, E.-G., and Claude, H.: Recent tropospheric ozone changes - a pattern dominated by slow or no growth, Atmos. Environ., 67, 331-351, https://doi.org/10.1016/j.atmosenv.2012.10.057, 2013.

Parrish, D. D., Millet, D. B., and Goldstein, A. H.: Increasing ozone in marine boundary layer inflow at the west coasts of North America and Europe, Atmos. Chem. Phys., 9, 1303-1323, https://doi.org/10.5194/acp-9-1303-2009, 2009.

Parrish, D. D., Lamarque, J.-F., Naik, V., Horowitz, L., Shindell, D. T., Staehelin, J., Derwent, R., Cooper,O. R., Tanimot,H., VolzThomas, A., Gilge, S., Scheel, H.-E., Steinbacher, M., and Fröhlic, M.: Long-term changes in lower tropospheric baseline ozone concentrations: Comparing chemistry-climate models and observations at northern midlatitudes, J. Geophys. Res.-Atmos., 119, 5719-5736, https://doi.org/10.1002/2013JD021435, 2014.

Pickering, K. E., Thompson, A. M., Kim, H. C., DeCaria, A. J., Pfister, L., Kucsera, T. L., Witte, J. C., Avery, M., Blake, D. R., Crawford, J. H., Heikes, B. G., Sachse, G. W., Sandholm, S. T., and Talbo, R. W.: Trace gas transport and scavenging in PEM-Tropics B South Pacific Convergence Zone convection, J. Geophys. Res., 106, 32591-32607, https://doi.org/10.1029/2001JD000328, 2001.

Rex, M., Wohltmann, I., Ridder, T., Lehmann, R., Rosenlof, K., Wennberg, P., Weisenstein, D. K., Notholt, J., Krüger, K., Mohr, V., and Tegtmeier, S.: A Tropical West Pacific OH Minimum and Implications for Stratospheric Composition, Atmos. Chem. Phys., 14, 4827-4841, https://doi.org/10.5194/acp-144827-2014, 2014.

Sauvage, B., Gheusi, F., Thouret, V., Cammas, J.-P., Duron, J., Escobar, J., Mari, C., Mascart, P., and Pont, V.: Medium-range midtropospheric transport of ozone and precursors over Africa: two numerical case studies in dry and wet seasons, Atmos. Chem. Phys., 7, 5357-5370, https://doi.org/10.5194/acp-7-5357-2007, 2007.

Schneider, P., Lahoz, W. A., and van der A, R.: Recent satellitebased trends of tropospheric nitrogen dioxide over large urban agglomerations worldwide, Atmos. Chem. Phys., 15, 12051220, https://doi.org/10.5194/acp-15-1205-2015, 2015.

Schoeberl, M. R.: A trajectory-based estimate of the tropospheric ozone column using the residual method, J. Geophys. Res., 112, D24S49, https://doi.org/10.1029/2007JD008773, 2007. 
Seinfeld, J. H. and Pandis, S. N.: Atmospheric Chemistry and Physics: From Air Pollution to Climate Change, 1326 pp., WileyInterscience, 2006.

Solomon, S., Qin, D., Manning, M., Alley, R. B., Berntsen, T., Bindoff, N. L., Bernstein, L., Bosch, P., Canziani, O., Chen, Z., Christ, R., Davidson, O., Hare, W., Huq, S., Karoly, D., Kattsov, V., Kundzewicz, Z., Liu, J., Lohmann, U., Manning, M., Matsuno, T., Menne, B., Metz, B., Mirza, M., Nicholls, N., Nurse, L., Pachaur,i, R., Palutikof, J., Parry, M., Qin, D., Randranath, N., Reisinger, A, Ren, J., Riahi, K., Rosenzweig, C., Rusticucci, M., Schneider, S., Sokona, Y., Solomon, S., Stott, P., Stouffer, R., Sugiyama, T., Swart, R., Tirpak, D., Vogel, C., and Yohe, G.: Technical summary, in: Climate Change 2007: The Physical Science Basis, edited by: Solomon, S., Qin, D., Manning, M., Chen, Z., Marquis, M., Averyt, K., Tignor, M., Miller, H. L., Contribution of Working Group I to the Fourth Assessment Report of the Intergovernmental Panel on Climate Change, Cambridge, UK/New York, NY, Cambridge University Press, 19-91, 2007.

Stevenson, D. S., Johnson, C. E., Collins, W. J., Derwent, R. G., and Edwards, J. M.: Future tropospheric ozone radiative forcing and methane turnover - The impact of climate change, Geophys. Res. Lett., 27, 2073-2076, 2000.

Thompson, A. M., Doddridge, B. G., Witte, J. C., Luke, W. T., Johnson, J. E., Johnson, B. J., Oltmans, S. J., and Weller, R.: A tropical Atlantic paradox: Shipboard and satellite views of a tropospheric ozone maximum and wave-one in January-February 1999, Geophys. Res. Lett., 27, 3317-3320, 2000.

Thompson, A. M. and Hudson, R. D.: Tropical Tropospheric Ozone (TTO) maps from Nimbus-7 and EarthProbe TOMS by the modified-residual method: Evaluation with sondes, ENSO signals and trends from Atlantic regional time series, J. Geophys. Res., 26961-26975, 1999.

Thompson, A. M., Witte, J. C., McPeters, R. D., Oltmans, S. J., Schmidlin, F. J., Logan, J. A., Fujiwara, M., Kirchhoff, V. W. J. H., Posny, F., Coetzee, G. J. R., Hoegger, B., Kawakami, S., Ogawa, T., Johnson, B. J., Vömel, H., and Labow, G.: Southern Hemisphere Additional Ozonesondes (SHADOZ) 1998-2000 tropical ozone climatology 1. Comparison with Total Ozone Mapping Spectrometer (TOMS) and ground-based measurements, J. Geophys. Res., 108, 8238, https://doi.org/10.1029/2001JD000967, 2003.

Thompson, A. M., Witte, J. C., and Smit, H. G.: Southern Hemisphere Additional Ozonesondes (SHADOZ) 1998-2004 tropical ozone climatology: 3. Instrumentation, station-to-station variability, and evaluation with simulated flight profiles, J. Geophys. Res., 112, D03304, https://doi.org/10.1029/2005jd007042, 2007.

Thompson, A. M., Balashov, N. V., Witte, J. C., Coetzee, J. G. R., Thouret, V., and Posny, F.: Tropospheric ozone increases over the southern Africa region: bellwether for rapid growth in Southern Hemisphere pollution?, Atmos. Chem. Phys., 14, 9855-9869, https://doi.org/10.5194/acp-14-9855-2014, 2014.

Thompson, A. M., Witte, J. C., Sterling, C., Jordan, A., Johnson, B. J., Oltmans, S. J., and Thiongo, K.: First reprocessing of Southern Hemisphere Additional Ozonesondes (SHADOZ) ozone profiles (1998-2016): 2. Comparisons with satellites and groundbased instruments, J. Geophys. Res.-Atmos., 122, 13000-13025. https://doi.org/10.1002/2017JD027406, 2017.
Trenberth, K. E.: Changes in precipitation with climate change, Clim. Res., 47, 123-138, https://doi.org/10.3354/cr00953, 2011.

Trenberth, K. E., Fasullo, J., and Smith, L.: Trends and variability in column-integrated atmospheric water vapor, Clim. Dynam., 24, 741-758, https://doi.org/10.1007/s00382-005-0017-4, 2005.

UNEP, Environmental Effects of Ozone Depletion: 1998 Assessment, United Nations Environment Programme, $205 \mathrm{pp}$. ISBN 92-807-1724-3, available at: https://www.esrl.noaa.gov/ csd/assessments/ozone/1998/ (last access: 9 February 2017), 1998.

Institut für Umweltphysik - Universität Bremen http://www.iup. uni-bremen.de/UVSAT/datasets/tropospheric-ozone-ccd, last access: 19 June 2018.

Valks, P. J. M., Koelemeijer, R. B. A., van Weele, M., van Velthoven, P., Fortuin, J. P. F., and Kelder, H.: Variability in tropical tropospheric ozone: Analysis with Global Ozone Monitoring Experiment observations and a global model, J. Geophys. Res., 108, 4328, https://doi.org/10.1029/2002JD002894, 2003.

Valks, P., Hao, N., Gimeno Garcia, S., Loyola, D., Dameris, M., Jöckel, P., and Delcloo, A.: Tropical tropospheric ozone column retrieval for GOME-2, Atmos. Meas. Tech., 7, 2513-2530, https://doi.org/10.5194/amt-7-2513-2014, 2014.

Verstraeten, W. W., Neu, L. J., Williams, E. J., Bowman, W. K., Worden, R. J., and Boersma, F. K.: Rapid increases in tropospheric ozone production and export from China, Nature Geosci. 8, 690-695, https://doi.org/10.1038/ngeo2493, 2016.

Voulgarakis, A., Savage, N. H., Wild, O., Braesicke, P., Young, P. J., Carver, G. D., and Pyle, J. A.: Interannual variability of tropospheric composition: the influence of changes in emissions, meteorology and clouds, Atmos. Chem. Phys., 10, 2491-2506, https://doi.org/10.5194/acp-10-2491-2010, 2010.

Wai, K. M., Wu, S., Kumar, A., and Liao, H.: Seasonal variability and long-term evolution of tropospheric composition in the tropics and Southern Hemisphere, Atmos. Chem. Phys., 14, 48594874, https://doi.org/10.5194/acp-14-4859-2014, 2014.

Weatherhead, E. C., Reinsel, G. C., Tiao, G. C., Meng, X.-L., Choi, D., Cheang, W.-K., Keller, T., DeLuisi, J., Wuebbles, D. J., Kerr, J. B., Miller, A. J., Oltmans, S. J., and Frederick, J. E.: Factors affecting the detection of trends: Statistical considerations and applications to environmental data, J. Geophys. Res., 103, 1714917161, https://doi.org/10.1029/98JD00995, 1998.

WHO: Health risks of particulate matter from long-range transboundary air pollution, available at: http://www.euro.who.int/ __data/assets/pdf_file/0006/78657/E88189.pdf (latest access: 19 June 2018), 2006.

Wilks, D. S.: Statistical Methods in the Atmospheric Sciences, 3rd ed., Oxford, Waltham, MA, Academic Press, 2011.

Witte, J. C., Thompson, A. M., Smit, H. G., Fujiwara, M., Posny, F., Coetzee, G., Northam, E., Johnson, B., Sterling, C., Mohamad,M., Ogino, S., Jordan, A., and da Silva, F.: First reprocessing of Southern Hemisphere ADditional OZonesondes (SHADOZ) profile records (1998-2015): 1. Methodology and evaluation, J. Geophys. Res.-Atmos., 122, 6611-6636, https://doi.org/10.1002/2016jd026403, 2017.

WMO (World Meteorological Organization): Global Ozone Research and Monitoring Project, Scientific Assessment of Ozone Depletion: 2010, Report No. 52, World Meteorological Organization, Geneva, Switzerland, 2-4 May 2011. 
WMO (World Meteorological Organization/International Global Atmospheric Chemistry: WMO/IGAC Impacts of Megacities on air pollution and climate, GAW Report No. 205, Ch. 7, 250-275, 2012.

$\mathrm{Xu}, \mathrm{X}$., and Lin, W.: Trends of tropospheric ozone over China based on satellite data (1979-2005), Adv. Clim. Change Res., 2, https://doi.org/10.3724/SP.J.1248.2011.00043, 2011.

Young, P. J., Archibald, A. T., Bowman, K. W., Lamarque, J.-F., Naik, V., Stevenson, D. S., Tilmes, S., Voulgarakis, A., Wild, O., Bergmann, D., Cameron-Smith, P., Cionni, I., Collins, W. J., Dalsøren, S. B., Doherty, R. M., Eyring, V., Faluvegi, G., Horowitz, L. W., Josse, B., Lee, Y. H., MacKenzie, I. A., Nagashima, T., Plummer, D. A., Righi, M., Rumbold, S. T., Skeie, R. B., Shindell, D. T., Strode, S. A., Sudo, K., Szopa, S., and Zeng, G.: Preindustrial to end 21 st century projections of tropospheric ozone from the Atmospheric Chemistry and Climate Model Intercomparison Project (ACCMIP), Atmos. Chem. Phys., 13, 2063 2090, https://doi.org/10.5194/acp-13-2063-2013, 2013.

Young, P. J., Naik, V., Fiore, A. M., Gaudel, A., Guo, J., Lin, M. Y., Fiore, A. M., Gaudel, A., Guo, J., Lin, M. Y., Neu, J. L., Parrish, D. D., Rieder, H. E., Schnell, J. L., Tilmes, S., Wild, O., Zhang, L., Ziemke, J. R., Brandt, J., Delcloo, A., Doherty, R. M., Geels, C., Hegglin, M. I., Hu, L., Im, U., Kumar, R., Luhar, A., Murray, L., Plummer, D., Rodriguez, J., Saiz-Lopez, A., Schultz, M. G., Woodhouse, M. T., and Zeng, G.: Tropospheric Ozone Assessment Report: Assessment of global-scale model performance for global and regional ozone distributions, variability, and trends, Elem. Sci. Anth., 6, 10, https://doi.org/10.1525/elementa.265, 2018.
Zhang, Y., Cooper, O. R., Gaudel, A., Thompson, A. M., Nédélec, P., Ogino, S. Y., and West, J. J.: Tropospheric ozone change from 1980 to 2010 dominated by equatorward redistribution of emissions, Nature Geosci., 9, 875-879, https://doi.org/10.1038/ngeo2827, 2016.

Ziemke, J. R., Chandra, S., and Bhartia, P. K.: Two new methods for deriving tropospheric column ozone from TOMS measurements: Assimilated UARS MLS/HALOE and convectivecloud differential techniques, J. Geophys. Res., 103, 22115, https://doi.org/10.1029/98JD01567, 1998.

Ziemke, J. R. and Chandra, S.: La Nina and El Ninoinduced variabilities of ozone in the tropical lower atmosphere during 1970?2001, Geophys. Res. Lett., 30, 1142, https://doi.org/10.1029/2002GL016387, 2003.

Ziemke, J. R., Chandra, S., and Bhartia, P. K.: A 25-year data record of atmospheric ozone in the Pacific from TotalOzone Mapping Spectrometer (TOMS) cloud slicing: Implications for ozone trends in the stratosphere and troposphere, J. Geophys. Res., 110, D15105, https://doi.org/10.1029/2004JD005687, 2005.

Ziemke, J. R., Joiner, J., Chandra, S., Bhartia, P. K., Vasilkov, A., Haffner, D. P., Yang, K., Schoeberl, M. R., Froidevaux, L., and Levelt, P. F.: Ozone mixing ratios inside tropical deep convective clouds from OMI satellite measurements, Atmos. Chem. Phys., 9, 573-583, https://doi.org/10.5194/acp-9-573-2009, 2009a.

Ziemke, J. R., Chandra, S., Duncan, B. N., Schoeberl, M. R., Torres, O., Damon, M. R., and Bhartia, P. K., Recent biomass burnings in the tropics and related changes in tropospheric ozone, Geophys. Res. Lett., 36, L15819, https://doi.org/10.1029/2009GL039303, 2009b. 